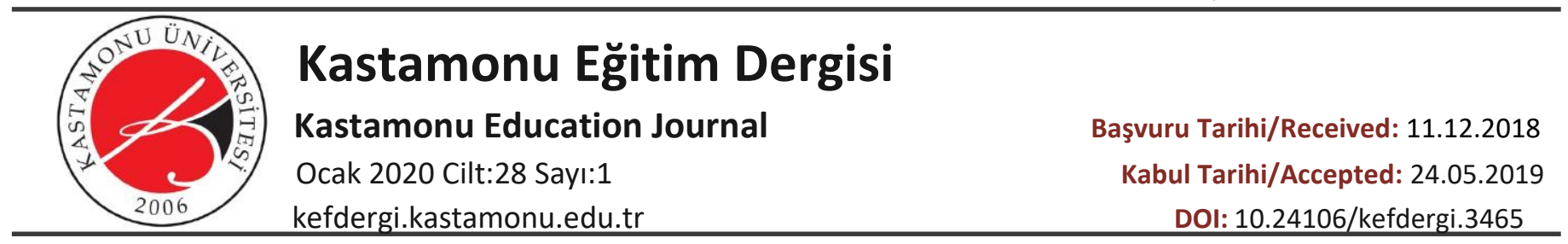

\title{
Fen Bilgisi Öğretmen Adaylarının Ortak Bilgi Yapılandırma Modeli Hakkındaki Görüşleri1
}

\section{The Pre-service Science Teachers Views' about Common Knowledge Construction Model}

Öz

\author{
Seda ÇAVUŞ-GÜNGÖREN², Ergin HAMZAOĞLU³
}

Öğretmen adaylarının bir öğretim modelin uygulamadaki olumlu ve olumsuz yönleri hakkındaki görüşlerinin değerlendirilmesi uygun eğitim ortamlarının oluşturulması için önemlidir. Bu araştırmanın amacı, Ortak Bilgi Yapılandırma Modeli (OBYM) ile bilimin doğasına yönelik ders planı hazırlayan öğretmen adaylarının bu model hakkındaki görüşlerini ortaya çıkarmaktır. Çalışmanın araştırma modeli nitel araştırma metodolojisinden durum çalışması olarak belirlenmiştir. Araştırma "Bilimin Doğası ve Bilim Tarihi” dersi kapsamında yürütülmüş ve toplam 25 öğretmen adayı katılmıştır. Bu araştırmada iki farklı veri toplama aracı yer almaktadır. Bunlar; OBYM ile hakkında belirlenen açık uçlu sorular ve yarı yapılandırılmış mülakatlardır. Yarı yapılandırılmış mülakatlarda katılımcı olan üç öğretmen adayı gönüllülük esasına dayalı olarak belirlenmiştir. Verilerin analizinde içerik analizi kullanılmıştır. Sonuçlar öğretmen adaylarının modeli öğrencinin kendi kendine öğrenmeyi, eski ve yeni bilginin ilişkilendirmesi gibi olumlu; zaman kullanımı, bireysel farklılıkların uygulamayı zorlaştırması gibi konularda olumsuz değerlendirdikleri yönündedir. Ayrıca bilimin doğası özelliklerinin bu modelle vurgulanabileceğini ifade etmişlerdir. Modelin uygulanmasında kalabalık sınıflarda uygulamasının zor olabileceği belirtilmiştir. Öğretmen adaylarına bilimin doğasını ders planlarına entegre ederek planlama yapmaya yönlendirmenin modelle ilgili görüşlerinde önemli bir farklılık oluşturmadığı belirlenmiştir. Sosyo-bilimsel konular, FTTÇ(Fen, Teknoloji, Toplum, Çevre) gibi modelin ön plana çıkardığı diğer bağlamlarda ders planlamaya yönlendirmenin ya da fen dışındaki başka bir alanla yaşanacak süreçlerin de benzer sonuçlar ortaya koyup koymayacağının araştırılması önerilmektedir.

Anahtar Kelimeler: ortak bilgi yapılandırma modeli, fen bilgisi öğretmen adayı, bilimin doğası, bilimin doğası öğretimi, fen öğretimi

\section{Abstract}

The evaluation of the preservice teachers' views on the positive and negative aspects of an instructional model is important for the creation of appropriate educational environments. The aim of this research is to reveal preservice science teachers' views about common knowledge construction model (CKCM) which integrating nature of science into their lesson plans. The research was designed as a case study from the qualitative research methodology. It was conducted within the Nature of Science and History of Science course and a total of 25 preservice science teachers participated. There are two data collection tools in this research. The first data collection tool is composed of open-ended questions about the CKCM, second is semi-structured interviews. Three preservice teachers in semi-structured interviews were determined on a voluntary basis. Content analysis was used in the analysis of the data. The results show that the preservice science teachers have both negative (time using and individual differences make the implementation difficult) and positive (self-learning, associate old and new knowledge) views about the CKCM. They expressed that the nature of science can be emphasized with this model. It has been stated that the application of the model may be time-consuming and difficult to apply in crowded classes. It was determined that directing preservice teachers to integrate nature of science into their lesson plans did not make a significant difference in the views of the model. Planning lesson plan with in other contexts that are prominent by the model, such as socio-scientific issues, the STSE(Science, Technology, Society, Environment), it is recommended to investigate whether the processes will produce similar results.

Keywords: common knowledge construction model, preservice science teachers, nature of science, nature of science teaching, science teaching

\footnotetext{
1 Bu çalışma birinci yazarın doktora tezinden üretilmiştir.

${ }^{2}$ Çanakkale Onsekiz Mart Üniversitesi Eğitim Fakültesi Matematik ve Fen Bilimleri Eğitimi Bölümü, Çanakkale, Türkiye, http://orcid.org/0000-0001-9521-0008

${ }^{3}$ Gazi Üniversitesi, Gazi Eğitim Fakültesi, Matematik ve Fen Bilimleri Eğitimi Bölümü, Kastamonu, Türkiye, http://orcid.org/0000-0001-6053-6796 Atıf / Citation: Çavuş-Güngören, S. ve Hamzaoğlu, E. (2020). Fen Bilgisi Öğretmen Adaylarının Ortak Bilgi Yapılandırma Modeli Hakkındaki Görüşleri. Kastamonu Education Journal, 28(1), 107-124. doi:10.24106/kefdergi.3465
} 


\section{Extended Abstract}

Introduction: The researchers stated that effective teachers are a critical factor for student learning (Hanuschin, Lee \& Akerson, 2010; Pongsanon, 2012). Teachers' ability to teach NOS is fundamental as well as their understanding of NOS for having students with desired understanding of NOS (Doğan, Çakıroğlu, Bilican \& Çavuş, 2013). The Common Knowledge Construction Model (CKCM) is one of the teaching models aimed at teaching NOS. The CKCM is a teaching model developed by Ebenezer and Connor (1998) and based on constructivist learning theory. CKCM serves as a model for teaching and learning because it is anchored in phenomenography, the Variation Theory of Learning. It is asserted that common knowledge in science means constructing reality that resides in the science also differs from those employed in everyday thinking or thinking in other contexts (Ebenezer et al., 2010). The CKCM consists of four interactive phases of teaching and learning: Exploring and Categorizing; Constructing and Negotiating; Translating and Extending; and Reflecting and Assessing. The researchers found that CKCM was effective in the development of students' NOS views (Biernacka, 2006; Bakırcl, 2014). Some research (Bakırcl, 2006) focus on teachers' views on CKCM, but it has been determined that the literature evaluating the views of preservice teachers on this model is limited. In this context, the purpose of this study is to reveal preservice science teachers' views about CKC which integrating nature of science into their lesson plans.

Method: This study was designed as a case study. The data for the study were collected throughout one school semester and total of 25 preservice science teachers were participated. During this time the participants were enrolled in the "Nature of Science and History of Science" course as part of their undergraduate elementary science education program. As part of this course, participants were engaged in different contextualized and de-contextualized NOS activities that explicitly addressing six target aspects of NOS. Each aspect of NOS was introduced to the participants explicitly through activities followed by group discussions on reflected NOS aspects through the activities. After the activities, target aspects of NOS were clearly emphasized and feedback was given by the researchers. The second objective of the course is to inform preservice teachers about CKCM. The training focused on the what CKCM is, how the model is used in classes, how NOS is reflected to course content and small applications were made with participants. In this process feedback provided to the pre-service teachers regarding the lesson plan preparation. There are two data collection tools in this research. The first data collection tool is composed of open-ended questions about the CKCM, second is semi-structured interviews. Three preservice teachers in semi-structured interviews were determined on a voluntary basis. Content analysis was used in the analysis of the data.

Results: The results of the analysis showed that the preservice teachers have both negative and positive views about the CKCM.. The preservice teachers evaluated each stage of CKCM and expressed their opinions in this direction. For example, it was determined that the opinions of the first phrase of OBYM related to the exploring and categorizing were similar to the suggestions of the model. The preservice teachers stated that preliminary information was revealed and misconceptions were determined at this step. The number of pre-service teachers who stated that misconceptions should be determined is also quite high. It was observed that pre-service teachers pointed out some points where CKCM was advantage in teaching. Emphasis on the NOS has been the most frequently mentioned positive characteristic of the model. The fact that the NOS is one of the important features that emphasize the teaching of the model in the learning environment (Biernacka 2006; Çepni et al., 2012; Ebenezer et al., 2010; Ebenezer and Fraser, 2001; Wood, 2012) and at the same time it is thought to have an effect on the subject. It is emphasized that the student is active, the learning environmental is student-centered and the teacher role is being a guide. The preservice teachers also stated that there are some limitations related to CKCM. The implementation of the model may cause a shortage of time and may be difficult to implement in crowded classes. It was determined that directing preservice teachers to integrate nature of science into their lesson plans did not make a significant difference in the views of the model. The results of the research show that the pre-service teachers are aware of the CKCM and its implementation and they express their views on the nature of the model. For the teachers and researchers who will plan a course on the nature of science with CKCM, the suggestions given by the teacher candidates are as follows; at the Exploring and Categorizing stage: the difference between observation and inference can be emphasized; during the Constructing and Negotiating stage; imagination and creativity, scientific knowledge is based on data from experiments and observations, how do scientists work? issues can be discussed, experiments and observations can be made; at the stage of Translating and Extending: it can be related to the social and cultural structure of science. Planning lesson plan with in other contexts that are prominent by the model, such as socio-scientific issues, the STSE (Science, 
Technology, Society, Environment), it is recommended to investigate whether the processes will produce similar results.

\section{Giriş}

Öğretmenlerin öğretim programını en iyi şekilde uygulayabilecek donanım kazanması, öğretmen yetiştirmenin en önemli hedefidir. Bu doğrultuda öğretim programın felsefesini ve temel öğrenme ilkelerini benimsemiş kısacası öğretmenlik pedagojisini kazanmış öğretmen adaylarının yetişmesi, kaliteli bir fen öğretiminin gerçekleşmesi için önemlidir. Kullanılan öğretim yöntemleri fen öğrenmeye yönelik pek çok kazanımı ortaya çıkarsa da modelin uygulayıcısı olacak fen bilgisi öğretmen adaylarının görüşlerini değerlendirmek mevcut eğitim ortamının geliştirilmesine katkı sağlayacaktır (Bozdoğan ve Altunçekiç, 2007). Çünkü öğretmen adaylarının fen bilimleri öğretim programı ile uyumlu ve etkili modeller, yöntemler konusunda yeterli donanıma sahip olarak mezun olmaları gerekir (Bakırcı, \& Çepni, 2014). Bu nedenle deneyim kazanacakları uygun ortamları hazırlanmalıdır. Mikro öğretim yöntemi bu deneyimlerin kazanılmasında etkili bir yöntemdir. Karaman (2014), mikro-öğretimin faydalarını şu şekilde özetlemiştir: (1) öğretmen adaylarının öğretim ile ilgili gerçekleri görmesini sağlar, (2) gelecek mesleklerindeki rollerini tanımalarına yardımcı olur, (3) öğretimi planlama, karar verme ve uygulamanın önemini kavramalarını sağlar, (4) öğretim becerilerinin gelişimine yardımcı olur, (5) öğretimde kendilerine olan güvenlerinin artmasına yardımcı olur.

Etkili bir öğretmenin, öğrencilerin öğrenmesinde kritik bir faktör olduğu konusunda yaygın bir fikir birliği vardır (Hanuscin, Lee, Akerson, 2010; Pongsanon, 2012). Fen eğitiminin temel amacının bilim okuryazarı bireyler yetiştirmek olduğu için öğretmenlerin doğru bilimin doğası öğretimi yapmalarının önemi de ortaya çıkmaktadır. Çünkü öğretmenlerin bilimin doğası konusunda bilgi sahibi olmaları ve öğretme kabiliyetleri, öğrencilerin bilimin doğasını daha iyi anlayabilmeleri için temel yapı olarak görülmektedir (Doğan, Çakıroğlu, Bilican ve Çavuş, 2013). Ortak Bilgi Yapılandırma Modeli (OBYM) bilimin doğası öğretimini hedefleyen öğretim modellerinden biridir (Bakırcı, Çalık ve Çepni, 2017). Araştırmacılar öğrencilerin bilimin doğası görüşlerinin gelişiminde de etkili olduğunu belirlemişlerdir (Biernacka, 2006; Bakırcı, 2014). Bazı araştırmacılar OBYM hakkında çalışmalar yürütmüşlerdir. Örneğin Bakırcı, Çepni ve Ayvacı (2015) öğretmenlerin, Çelik, Pektaş ve Karamustafaoğlu (2018) ise öğretmen adaylarının OBYM hakkındaki görüşlerini araştırmıştır. Öğrencilerin öğrenmelerinde öğretmen rolünün önemi ve öğretmen adaylarının yaşadığı deneyimlerin kattığı kazanımlar düşünüldüğünde öğretmen adaylarının OBYM hakkında görüşlerinin belirlenmesinin önem taşıyacağı söylenebilir. Ancak öğretmen adaylarının görüşlerine dair bilgiler oldukça sınırlıdır. Ayrıca gelecekte yapılması planlanan OBYM uygulamalarının daha iyi tasarlanması ve ihtiyaç analizinin yapılması için öğretmen adaylarının OBYM'ye yönelik görüşlerinin mikro öğretim sonucunda belirlemenin önemli olduğu söylenebilir. Bu bağlamda bu araştırmanın amacı, OBYM ile bilimin doğasına yönelik ders planı hazırlayan öğretmen adaylarının bu model hakkındaki görüşlerini araştırmaktır.

\section{Ortak Bilgi Yapılandırma Modeli (OBYM)}

Ebenezer ve Connor (1998) tarafından geliştirilen Ortak Bilgi Yapılandırma Modeli (OBYM) yapılandırmacı öğrenme kuramını esas alan bir öğretim modelidir (Biernacka, 2006). Bu modelle, bireylerin etraflarındaki fenomenlerle ilgili yaşantılardan bilgiyi nasıl yapılandırdığını ve kavramsal değişim süreçleri belirlenmektedir (Ebenezer, Chacko, Kaya, Kaya, \& Ebenezer, 2010). Model, temelde teorik kökleri bakımından beş farklı eğitimcinin çalışmalarına dayanmaktadır (Çepni, Özmen ve Bakırcı, 2012). Bunlardan birincisi Marton'un (Variation Theory of Learning) "Öğrenme Varyasyonu Teorisi", ikincisi Piaget'in kavramsal değişim çalışmaları (Ebenezer ve diğer., 2010) ve üçüncüsü Bruner'in dili, kültürün simgesel sitemi olarak gören görüşüdür (Biernacka, 2006). Dördüncüsü Vygotsky'nin sosyal çevrenin yönlendirdiği (Zone of Proximal Development) “yakınsal gelişim alanı" ve beşincisi ise Doll'un (Scientific Discourse) "bilimsel söylem" ve müfredat gelişimiyle ilgili "post modern" düşünceleridir (Biernacka, 2006).

Bilişsel öğrenmeyi hedefleyen bir öğretim modeli olan OBYM, doğal olgularla öğrenci arasında hem kişisel hem de sosyal bir etkileşim yoluyla evrene yönelik düşünceler, inançlar oluşturmayı amaçlar (Bakırcı ve Çepni, 2012; Biernacka, 2006). Bu durum, fen öğrenimini hem psikolojik bir perspektif, hem tarihi ve felsefi bakış açısı, hem de fen-teknolojitoplum-çevre (FTTÇ) yöneliminin uygun bir şekildeki bütünleştirilmesiyle gerçekleşir (Biernacka, 2006). Dolayısıyla bu model, kavramsal değişim, bilimin doğası öğretimi, fen-teknoloji-toplum-çevre ilişkisinin tek bir süreçte öğretimine olanak sağlamaktadır. Model dört basamaktan oluşmaktadır. 


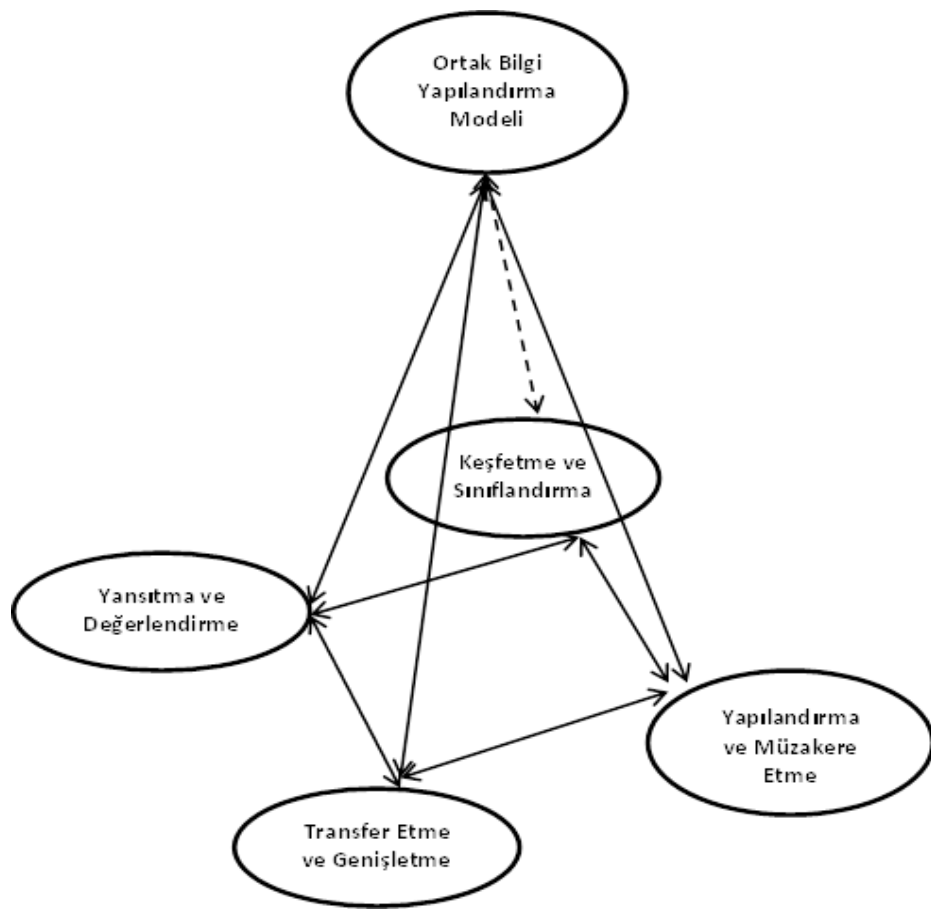

Şekil 1. OBYM’nin Temellendirildiği Dört Basamak (Biernacka, 2006; Ebenezer ve diğer., 2010)

Keşfetme ve Sınıflandırma (Exploring and Categorizing): Modelin birinci basamağı olan bu aşamanın amacı, öğrencilerin ön bilgilerini, daha önce yaşamış oldukları deneyimleri ve doğal dünya hakkındaki algılarını ya da sosyal (Sosyo-bilimsel konular. Örneğin; fen konularıyla ilişkili klonlama, alternatif enerji kaynakları gibi tartışmalı sosyal konular.) olgulara ne anlam yüklediğini ortaya çıkarmaktır (Biernecka, 2006). Öğretmen, öğrencilerin ön bilgilerini, hazır bulunuşluklarını ortaya çıkaran, dikkat çekici ve onları motive edecek bir aktivite(ler) gerçekleştirir. Bu aktivite bir gösteri, resim, diyagram, video veya beyin fırtınası olabilir. Amaç, öğrencilerin söz konusu olguyla ilgili yaşantılarını, kavramalarını ortaya çıkarmak, dikkatlerini olgu üzerine çekmek ve sınıflandırma yapmasını sağlamaktır. Bu süreçte öğrencilerin konuyla ilgili alternatif kavramları tespit edilir ve bilimin doğası konusunda haberdar olmaları sağlanır (Bakırcı \& Çepni, 2014).

Öğretmenin rolü, öğrencilerin görüşlerini destekleyen ya da reddeden ifadeler kullanmak ve pozitif, destekleyici bir ortam oluşturmaktır. Bu süreçte öğrenci meraklanmaya ve keşfetmeye başlar. Sınıf içerisinde paylaşımın açık bir şekilde yapılması da öğrencinin kendi bilgisinin farkına varmasına ve arkadaşlarınınki ile kendi bilgisini kritik etmesine imkân sağlanır. Sonuç olarak öğrenci kendi bilgisinin ya da, bilimsel bilginin değişebilir olduğunu, gelişim ve değişim için esnek bir yapıda olduğunu görme şansı yakalar. Bilimin, doğadaki olguları araştıran ve açıklayan bir disiplin olduğunun farkına varır (Biernacka, 2006). Keşfetme ve sınıflandırmada basamağında; kavram haritası, sınıf tartışmaları, yarı yapılandırımış görüşme, TAGA stratejisi (tahmin, açıklama, gözlem ve açıklama), beyin fırtınası, yazarak ya da çizerek cevaplanan sorular kullanılabilir.

Yapılandırma ve Müzakere etme (Constructing and Negotiating): Modelin ikinci basamağı olan bu aşamada, programdaki kazanımlar ile öğrencilerin birinci basamakta açığa çıkarılan kavramlarıyla ilgili müzakere edilir. Bunun için öğretmenin kontrolünde öğretmen-öğrenci veya öğrenci-öğrenci arasında ön bilgiler göz önünde tutularak yeni bilgilerin kazanılması için görüşmeler gerçekleştirilir (Bakırcı \& Çepni, 2014). Bu görüşmeler yoluyla da yeni bilgiyi içselleştirmesi beklenir. Öğrenciler bu aşamada oluşturulan müzakere, görüşme, bilgiyi paylaşma ortamlarıyla bilimsel bilginin nasıl üretildiğine ve bilim insanlarının nasıl çalıştıklarına dair fikir sahibi olurlar. Örneğin; öğretmenle yapılan müzakereler sırasında bilim insanlarının da sosyal çevreleriyle paylaşımlarda bulundukları belirtir. Bilimsel bilgiyi geliştirmek için bilim insanlarının hayal güçlerini ve yaratıcılıklarını kullandıkları ve bilimsel bilginin deneylerden elde edilmiş verilere dayalı doğası vurgulanır.

Öğrenciler bu aşamada; bilimin tamamlanmış ve kesin bilgiler içermediğini, kendini yeni edinilen bilgiler ya da gözlemler yoluyla tekrar ilerleyeceğini fark ederler. Bilimin hem evrimsel bir yapısı olduğunu hem de devrimsel 
özellikler taşıdığını öğrenirler. Bu aşamada ayrıca; tek bir bilimsel yöntemin olmadığı, pek çok farklı yöntemin olduğu, bilimsel bilginin geliştirilmesi için verilerin, delillerin önemi ve teorilerle kanunlar arasında bir fark olduğu konularına değinilir (Biernacka, 2006). Bu aşamada araştırma-sorgulamaya dayalı etkinlikler, problem çözme etkinlikleri, işbirlikçi öğrenme teknikleri, büyük ya da küçük sınıf tartışmaları, TAGA vb. yöntemler kullanılabilir.

Transfer Etme ve Genişletme (Translating and Extending): Modelin üçüncü basamağı olan bu aşamada, öğrencilerin öğrenmiş oldukları kavramları günlük yaşamla ilişkilendirmeleri beklenir. Ayrıca, kazandıkları kavramları kullanarak çevrelerine ya da topluma yönelik problemler için çözüm üretmeye çalışıllar (Biernacka, 2006; Ebenezer ve diğer., 2010). Öğrenciler bu süreçte, sadece kazandıkları kavramları değil aynı zamanda teknoloji, toplum ve çevre ilişkisi çerçevesinde eleştirel düşünce yapısını da kullanırlar (Ebenezer ve diğer., 2010). Yani bilgilerini günlük yaşamla ilişkilendirirler. Fen programında da yer alan Fen-Teknoloji-Toplum-Çevre bağlamı kullanılarak sosyo-bilimsel konular hakkında düşünmeleri sağlanır. Öğrencilerin sosyal sorumluluk duygusu kazanmaları ve bilimin sosyal ve kültürel yapısı hakkında bilgi sahibi olmaları hedeflenir (Biernacka, 2006; Ebenezer ve diğer., 2010). Bakırcı ve Çepni (2014) bu aşamada en az bir bilimin doğası özelliğinin kazandırılması gerektiğini de belirtmiştir. Bu basamakta 5E modelinin derinleştirme basamağında olduğu gibi gerçek yaşamla ya da başka konu alanlarıyla bağlantılar yapılabilir. Materyal tasarımı, mühendislik ve teknoloji ile ilişkilendirmeler ya da bir problemi çözmeye yönelik etkinlikler bu basamakta yapılabilir.

Yansıtma ve Değerlendirme (Reflecting and Assessing): Modelin son basamağı olan bu aşamada öğretim sürecinde sahip olunan kavram yanılgılarının bilimsel bilgilerle değişip değişmediğine yönelik değerlendirme yapılır. Ancak Çepni, Özmen ve Bakırcı (2014), geleneksel ölçme ve değerlendirme yöntemlerinin bilgiyi ve kavramsal değişimi, kavramsal seviyede değerlendirirken ki yetersizliğinden dolayı, alternatif ölçme ve değerlendirme yöntem ve teknikleri kullanılması gerektiğini belirtmişlerdir. Çünkü alternatif ölçme ve değerlendirme yöntemleri öğrenilenlerin ne kadarının kazanıldı̆ına, anlamlandırıldığına ve öğrenme sürecinin tamamına odaklanır. Bunun paralelinde kavramsal değişim sürecini göz önünde bulundurulduğunda ise yapılan ölçme değerlendirme ile sadece ne öğrenildiğine değil, kavramların nasıl öğrenildiği ve zihinde yapılandırıldığı ortaya çıkarılır (Bakırcı ve Çepni, 2012). Bu aşamada oluşturulacak etkinliklerin tüm bu özellikler göz önünde bulundurularak yapılması gerekir. Ayrıca, Bakırcı ve Çepni (2014) değerlendirme sürecinin, öğrencilerin bilimsel bilgilerinin yanı sıra bilimsel süreç becerilerini, bilimsel davranış, tutum, inanç ve sosyal becerilerini de kapsayacak şekilde düzenlenebileceğini belirtmiştir. Yansıtma ve değerlendirmeye yönelik etkinliklerde alternatif ölçme ve değerlendirme yöntem ve tekniklerine paralel olarak; öğrendikleri bilginin nasıl kullanıldı̆̆ını sorulabilir, öğrendiklerini bir problemi çözmek için bir aktivite planlanabilir, öğrencilerden diyaloglarını/tartışmalarını yorumlamaları istenebilir, elde ettiğiniz sonuçlar neler?-ne öğrendiniz?öğrendiğinizi nasıl kullanacaksınız? gibi sorular yöneltilebilir.

Temelinin 1998 yılında Ebenezer ve Connor tarafından "Learning to teach science: a model for the 21 centrury" isimli kitapla atıldığı belirlenen OBYM'nin, öğretim metodu olarak kullanıldığı sınırlı sayıda çalışma olduğu tespit edilmiştir (Bakırcı ve Çepni, 2012). Ebenezer ve Connor tarafından yayımlanan kitaptan sonra ilk çalışmayı 2001 yılında Ebenezer ve Fraser yapmıştır. Birinci sınıftaki kimya mühendisliği öğrencilerinin çözünürlük sırasında meydana gelen enerji değişimleri hakkındaki kavramları araştırımıştır. Fenomenografi yönteminin kullanıldığı çalışmada üç farklı tuzlu su çözeltisindeki enerji değişimi üzerine bireysel görüşmeler gerçekleştirilmiş. Yapılan analiz sonucunda fenomenografik yöntemle oluşturulan kategoriler ortak bilgi yapılanma modelinin bir öğrenme metodu olarak kullanılması gerektiğini ortaya çıkarmıştır. Buna sebep olarak da öğrencilerin ifade ettikleri kavramlar ortak bir öğrenme yapısını işaret etmiştir. Ebenezer ve diğerleri (2010) fenomenografiyi ön plana çıkaran, OBYM'nin bir öğretim metodu olduğu ve kavramsal değişim için kullanıldığını yansıtan bir çalışma düzenlemişlerdir. illköğretim 7. sınıf öğrencileri boşaltım ünitesi kavramları üzerinde uygulanan deneysel bir çalışma olmuştur. Araştırma sonuçları, deney grubunun söz konusu kavramlar hakkında daha başarılı olduklarını göstermiştir. Ayrıca araştırma OBYM'nin kavramsal değişim için etkili bir yöntem olduğu ifade edilmiştir.

Bakırcı, Çalık ve Çepni (2017) çok az sayıda çalışmanın, OBYM'nin etkilerini farklı sınıf seviyesi ve / veya denekleri farklı olan bağımlı değişken(ler) üzerindeki etkilerin incelendiğini ifade etseler de, modelin kavramsal anlama (Kıryak, 2013) ve fen okuryazarlığı geliştirme (Bakırcı, Altun, Şahin ve Sağdıç, 2018) konularındaki başarısını araştıran araştırmacılar olmuştur. Örneğin Biernacka (2006), OBYM yöntemini kullanarak 5. sınıf öğrencilerinin "hava" isimli ünite içerisinde, bilimsel okuryazarlık gelişimlerini incelemiştir. Araştırmanın sonucunda öğrencilerin bilimsel okuryazarlığın "bilim nedir" boyutunda hava kavramı ve hava olaylarıyla ilgili ilkeler hakkında bilgi sahibi olmuşlardır. Bilimsel okuryazarlığın "bilim nasıldır?" boyutunda, bilimsel bilginin değişebilir, sosyal ve kültürel olaylarla ilişkili, deneysel, bilim insanlarının hayal gücü ve yaratıcılığına dayanan özelliklerde olduğunun farkına varmışlardır. Öğrenciler bilimsel okuryazarlığın "niçin bilim?" boyutunda bilim-teknoloji-toplum-çevrenin birbiriyle ilişkili olduğunun farkına 
varmışlardır. Ayrıca öğrenciler, fen bilimine karşı tutumlarının pozitif olarak geliştiğini, fen öğrenmeye karşı merak ve isteklerinin arttığını belirtmiştir. Bakırcı (2014), ise OBYM ile tasarlanmış öğrenme ortamının ışık ve ses konularının öğrenilmesine olan etkisini araştırmıştır. Bununla birlikte, tasarlanan öğretim materyallerinin uygulama sürecinin, öğrencilerin eleştirel düşünmelerine ve bilimin doğası görüşlerine olan etkisini de incelemiştir. Araştırmanın bulgularına göre, öğrencilerinin, bilimin doğası konusunda farklı görüşlere sahip oldukları ve OBYM'nin alternatif kavramların ortaya çıkarılmasında etkili olduğunu belirlenmiştir. Wood (2012) tarafından yapılan araştırmada ise öğrencilerin asit-baz konusuyla ilgili kavramsal değişim ve başarılarında öğrenme ve öğretme modeli olarak OBYM'nin etkisini ve öğretmenin sınıf içi uygulaması incelenmiştir. Sonuçlar öğrencilerin asit-baz ile ilgili kavramsal değişimlerinin gerçekleştiği, günlük yaşantılarında kimya dilini kullanmaya başladıkları, OBYM’nin kavramsal değişim ve başarı gelişimi için kullanılabilecek bir yöntem olduğu belirlenmiştir. Yine Caymaz ve Aydın (2019) OBYM'nin yedinci sınıf öğrencilerinin elektrik enerjisi ünitesine ilişkin kavramsal anlamalarına olumlu etkisi olduğunu ifade etmişlerdir. Bu doğrultuda, OBYM’nin alternatif kavramları ortaya çıkarma, kavramsal değişim, kavramsan anlam, bilimin doğası öğrenimi ve bilimsel okuryazarlık kazandırma konularında etkili bir öğretim yöntemi olduğu söylenebilir.

Bakırcı ve Çepni (2012), OBYM'nin ortaya atılma gerekçelerini ve teorik temellerini ortaya koyan çalışmasında, ilgili alan yazını detaylı bir şekilde irdelemenin yanında fen programıyla ilgili bazı sentezler de sunmuşlardır. Modelin nasıl ortaya çıktığına, hangi teorik temellere dayandığına, modelin içeriğine, 5E yöntemiyle olan benzerlik ve farklılıklara, öğretim metodu olarak kullanıldığında öğrenmeye ne tür katkılar sağlayacağına dair detaylı bir araştırma yapılmıştır. OBYM’nin, ülkemizde 2004 yılı fen ve teknoloji programın içeriğiyle paralel olduğuna, bunun yanında sosyobilimsel (GDO gibi konular) boyutunun zayıf olarak görülen 2013 fen bilimleri programına, modelin sahip olduğu bu boyutuyla katkı sağladığını ifade etmişlerdir (Bakırcı, \& Çepni, 2014). Ayrıca Çepni ve arkadaşları (2012) da fen programıyla ilgili bazı analizlerde bulunmuşlardır. Buna göre araştırmacılar, Fen ve Teknoloji dersinin öğretiminde genellikle 5E öğrenme modelinin tercih edildiğini, alan yazınında bu modelinde uygulanmasında bazı sınırılıkların yaşandığını belirtmişlerdir. Bu durumun fen eğitimcilerini yeni modeller geliştirmeye yönlendirdiğini ve bu modellerden birisinin de OBYM olduğunu, modelde ön plana çıkan bilimin doğası, fenomenografi ve kavramsal değişim gibi konular olduğuna dikkat çekmişlerdir.

Türkiye' de sıklıkla öğretmenler tarafından tercih edilen öğretim yöntemi olan 5E modeli ve OBYM bazı noktalarda örtüşmüştür. Ancak birçok farklılıkların olduğu da anlaşılmıştır (Bakırcı ve Çepni, 2012). 5E modeli ve OBYM arasındaki en önemli benzerlik, her iki modelinde yapılandırmacı yaklaşımı benimsemiş olmasıdır. Bunun yanı sıra; $5 \mathrm{E}$ ve OBYM’nin "giriş, keşfetme ve sınıflandırma" aşaması öğrenciyi motive etme, konuya dikkat çekme ve ön bilgilerini ortaya çıkarma konusunda benzerlik gösterirken, bu aşamada öğrencilerin kendi bilgilerinin doğruluğunu denemesi, çeşitli gözlemler yapması, hedeflenen kavrama yönelik deneyim kazanması ve bilgiyi birinci aşamada keşfetmeye başlaması açısından farklılıklar içermektedir. Ayrıca, OBYM'de tasarlanan içeriğin bilimin doğası ile ilişkilendirilmesi gerekmektedir. 5E modelinde bilimin doğası ilişkilendirmesi zorunlu değildir. Bununla birlikte her iki modelde de öğretmen rehber konumunda olsa da 5E modelinde öğretmen "açıklama basamağında" konunun daha iyi anlaşılması adına öğrenci açıklamalarından sonra aktif bir rol üstlenir. Oysaki OBYM'de böyle bir aşama veya içerik bulunmamaktadır. Bu nedenle OBYM dört, 5E modeli ise beş aşamadan oluşmaktadır.

Bu modelin diğer modellerden en önemli farklarından biri de transfer etme ve genişletme aşamasında fenteknoloji-toplum-çevre ilişkisinin açık uçlu sorular vasıtasıyla ön plana çıkarmasıdır (Bakırcı ve Çepni, 2012). Bu ilişkilendirme, öğrencinin edindiği bilgileri diğer disiplinlere aktarmasını sağladığı gibi toplumsal bakış açısıyla iyi bir vatandaş olması konusunda motive edeceği de söylenebilir (Biernacka, 2006). Bu modelde temel anlayış, öğrencilerin kendi öğrenmelerinin farkında olmalarını sağlamaktır. Süreç içerisinde kendi kişisel fikirlerini gözden geçirmesi ve yeniden oluşturmaları sağlanır. Bununla birlikte, öğrencilerin daha bilimsel düşünmeleri için uygun etkinlikler tasarlanmalı, yapılacak mülakatlar ve analizler yoluyla desteklenmelidir. Böylece öğrenciler bilimsel bilgilere keşfederek, araştırma ve sorgulama yoluyla öğrenebileceklerini de anlarlar (Ebenezer ve diğer., 2010).

Çelik, Pektaş ve Karamustafaoğlu, (2018), araştırma sorgulamaya dayalı öğrenmeyi kolaylaştıran OBYM, 5E ve STEM yaklaşımlarının öğretmen adayları tarafından avantajlar, dezavantajlar, bilişsel alan, beceriler, duyuşsal alan gibi konularda karşılaştırmalarını istemiştir. Araştırma sonuçları öğretmen adaylarının OBYM’nin bilimin doğası, ekip çalışması ve tartışma kültürü açısından diğer yöntemlerden daha avantajlı olarak değerlendirildiğini göstermiştir. Ancak ilgili alan yazın incelendiğinde öğretmen, öğretmen adayı gibi öğreticilerin model hakkındaki görüşlerinin değerlendirildiği sınırlı sayıda çalışma olduğu görülmektedir. OBYM’nin öğrenciye kazandırmayı hedeflendiği bilimin doğası gibi bir bağlamda öğretim tasarımına odaklanmanın modelin genel yapısını değerlendirirken bir farklılık oluşturma durumu araştırılmamıştır. 


\section{Araştırmanın Amacı ve Önemi}

Bir öğretim modeli hakkında uygulayıcısı olan eğitimci görüşlerinin belirlenmesi teorik yapı ile uygulama arasındaki bağın kurulması için önemlidir. Alan yazınında pek çok araştırmacı da bir öğretim yöntemi/modeli/yaklaşımı (proje tabanlı ve geleneksel öğretim-Ay, 2013; $5 E$ öğretim modeli-Bozdoğan ve Altunçekiç, 2007; ArgümantasyonNamdar ve Tuskan, 2018, Bağlam Temelli Yaklaşım-Topuz, Gencer, Bacanak ve Karamustafaoğlu, 2013; STEM eğitimiYıldırım ve Türk, 2018) hakkında öğretmen adaylarının görüşlerini araştırmıştır. Mesleğe başladıklarında bu öğretim modellerini kullanan öğretmen adaylarının ne bildikleri, sınıf içi uygulamalarına ve öğrenmeye yansıyacaktır (Yazar, 2015). Ancak öğretmen adaylarının bu modelin nasıl kullanıldığı konusunda özel bir eğitim almaları, bu modelin yaşantılarını öğrenen olarak deneyimlemeleri, OBYM öğretim sürecini ve uygulanabilirliğini mikro öğretim gibi bir yöntemle değerlendirmeleri gerekir. Çünkü öğretmen adaylarının öğretim süreciyle ilgili deneyimleri arttıkça sorunlar ve kaygılar azalır (Ay, 2013). Öğreticilerin bu modelin uygulamasıyla ilgili görüşlerine dair çok az şey bilinmektedir. Öğretmen adaylarının bilimin doğası bağlamında bu modeli kullanarak planlama yapmaları ve bunu mikro öğretimle deneyimlemeleri ile modelin özellikleri karşılaştırıldığında bu yönlendirmenin bir farklılık oluşturup oluşturmayacağı önemli bir konudur. Bu nedenle bu araştırma; OBYM modelini bilimin doğası bağlamında ders planlayarak deneyimleyen ve mikro öğretimle uygulama fırsatı yakalayan öğretmen adaylarının yaşantılarından yola çıkarak "OBYM hakkındaki görüşleri nelerdir?" sorusuna cevap aramaktadır. Araştırmada öğretmen adaylarının OBYM'yi bilimin doğası öğretimi bağlamında planlama yapma ve mikro öğretimle deneyimlemelerine yönlendirilerek tek başına bir öğretim yöntemini değerlendirilmesinin dışına çıkılmıştır. Sonuçların OBYM ile öğrenme süreçlerinin tasarımında ve öğretim aşamalarında dikkat edilmesi gereken hususların belirlenmesinde öğreticilere yol gösterici olacağı düşünülmektedir

\section{Yöntem}

\section{Araştırmanın Modeli}

Bu çalışmanın araştırma modeli nitel araştırma metodolojisinden durum çalışması olarak belirlenmiştir. Durum çalışmaları “Nasıl?” ve "Neden?" sorularına cevap arayan (Yin, 2003, s. 22) nitel sorgulamanın en yaygın yoludur (Stake, 2005 , s. 443). Durum çalışması, doğal bir çevre içerisinde gerçekleştirilerek, söz konusu konunun bütüncül olarak ele alınmasını hedefler (Yıldııım \& Şimşek, 2006). Temel prensip durumun özel bir yer, özel bir zaman gibi parametrelerle sınırlandırılmış olmasıdır (Merriam, 2013, s. 41). Araştırmada da OBYM ile bilimin doğası bağlamında ders planı hazırlayan öğretmen adaylarının bu modelle ilgili değerlendirmeleriyle sınırlandırılmıştır.

\section{Çalışma Grubu}

Bu araştırmada olasılık temelli olmayan örnekleme yöntemlerinden amaçlı örneklem modeli kullanılmıştır. Amaçı örneklem modelinde, belirli bir amaç doğrultusunda araştırmanın konusunu oluşturan kişi, olay ya da durum hakkında derinlemesine bilgi toplanır. Bu modelinin kullanılması, araştırmada seçilen örneklemin, araştırmacının araştırma problemlerine cevap bulacağına inandığı kişilerden oluştuğu kabulüne dayanır (Şahin, 2009, s. 125). Öğretmen adaylarının hem bilimin doğası hem de OBYM hakkında bilgi sahibi olmaları araştırmanın ön kabullerinden biridir. Sonuç olarak, bu araştırmada katılımcıların OBYM ile bilimin doğası öğretimine yönelik ders planlamaları ve mikro öğretim uygulaması sonunda modelle ilgili görüşleri değerlendirildiği için Bilimin Doğası ve Bilim Tarihi dersini alan 3. sınıf Fen Bilgisi öğretmen adayları ile gerçekleştirilmiştir. Araştırmaya 25 öğretmen adayı katılmıştır. Yarı yapılandırılmış mülakatlarda katılımcı olan üç öğretmen adayı gönüllülük esasına dayalı olarak belirlenmiştir.

\section{Uygulama Süreci}

Bu çalışma, fen bilgisi öğretmenliği lisans programının VI. döneminde yer alan "Bilimin Doğası ve Bilim Tarihi" dersi kapsamında gerçekleştirilmiştir. Ders bilimin doğası konusundaki bir uzman (ders yürütücüsü) ve araştırmacı tarafından yürütülmüştür. Dersin birinci hedefi katılımcıların bilimin doğası konusundaki görüşlerini geliştirmek olmuştur. Bu kapsamda bilimin doğası özellikleri-, uzmanların- önerdiği - (Lederman, 2007) doğrudan-derin düşündürücü yaklaşım (explicit-reflective approach) kullanılarak etkinlikler (Doğan ve diğer., 2013) vasıtasıyla tanıtılmıştır. Öğretmen adaylarına bilimin doğası konusunda düşünme, özelliklerini tartışma ve etkileşimde bulunarak etkinlikleri uygulama imkânı sağlanmıştır. Etkinlikler sonrasında bilimin doğası ile ilgili özellikler açık bir şekilde 
vurgulanmış ve dersin yürütücüsü tarafından dönütler verilmiştir. Ayrıca etkinlikler sonrasında hedeflenen bilimin doğası özellikleri tartışmaya açılmış, soru cevap yöntemi ile öğretmen adaylarının bu konudaki görüşlerini yansıtmaları sağlanmıştır. Daha sonra Fen Bilimleri dersi öğretim programındaki (MEB, 2013) bilimin doğasına yönelik içerik sunmuş ve öğretmen adayları ile bu içeriğin nasıl uygulanacağı yönünde tartışma ortamı oluşturulmuştur.

Dersin ikinci hedefi OBYM konusunda öğretmen adaylarını bilgilendirmektir. Bu kapsamda "OBYM nedir? Nasıl uygulanır? Bilimin doğası bu yöntemlerle hazırlanmış ders planlarıyla nasıl bütünleştirilir?" sorularına cevap olacak bir eğitim verilmiştir. Bu eğitim sürecinde fen dersi içeriği ile ilişkilendirilmiş bilimin doğası etkinlikleri yapılmış ve örnek ders planları gösterilmiştir. Bu uygulamalarda farklı sınıf seviyelerde yer alan fosiller, bitkilerde büyüme konularıyla ilgili örnek ders planları gösterilmiş ve bu ders planlarında yer alan etkinliklerin nasıl uygulanacağı, öğretmen adaylarının katılımıyla uygulamalı olarak aktarılmıştır. Örnek uygulamalarda kullanılan teknikler; keşfetme ve sınıflandırmada için soru cevap, sınıf tartışması; yapılandırma ve müzakere etme için problem çözme; transfer etme ve genişletme için örnek olay; yansıtma ve değerlendirme için büyük sınıf tartışması içermektedir. Ayrıca Smylie (1989) tarafından da öğretmenlerin öğretim uygulamalarına model olacak ve örnek etkinlikler içeren akademik yayınların paylaşılması önerisini göz önünde bulundurarak, araştırmacı öğretim modeliyle ilgili akademik çalışma (Bakırcı ve Çepni, 2012) paylaşmış ve bu yöntemle ilgili ulaşabilecekleri başka kaynaklar önermiştir. Bu sürecin sonunda öğretmen adaylarının OBYM'yi kullanarak ders planı hazırlamaları istenmiştir. Böylece öğretimi planlama konusunda sorumluluk almaları, kendi donanımlarını ders planlarına yansıtmaları, modeli ve aşamalarını daha iyi kavramaları, daha etkili değerlendirme yapmaları için uygun ortam sağlanmıştır.

Öğretmen adaylarının planlama sürecini desteklemek ve nasıl değerlendirilecekleri konusunda bilgilendirmek için “OBYM Ders İçeriğini Değerlendirme Formu” verilmiştir. Bu form hazırlanırken Çepni, Özmen ve Bakırcı'nın (2012) birlikte yapmış oldukları çalışmadan yararlanılmıştır. Ayrıca ders planlarının hazırlanması sırasında araştırmacı tarafından dönüt verilmiş, sunumlarını yapmadan önce ders içerisinde diğer gruplarla paylaşılmıştır. Böylece gruplara kendi akranları tarafından da dönüt verilmesi, güçlü ve zayıf yanların tartışılması sağlanmış ve planın tekrar iyileştirilmesi için şans verilmiştir. Son olarak öğretmen adayları mikro-öğretim yoluyla ders planlarını sunmaları ve modeli deneyimlemeleri hedeflenmiştir. Bu deneyim sonunda bu model hakkında ne düşündükleri bu araştırma ile belirlenmiştir.

\section{Veri Toplama Araçları}

Bu araştırmada iki farklı veri toplama aracı yer almaktadır. Birinci veri toplama aracı olarak OBYM ile hazırlanan ders planlarının özellikleri ve sınırlılıklarını yazmaları istenen açık uçlu sorulardır (Ortak Bilgi Yapılandırma Modeline göre hazırlanmış bir ders planının özellikleri nelerdir? Örnek vererek kısaca açıklayınız. Ortak Bilgi Yapılandırma Modeline göre hazırlanmış bir ders planının sınırlılıkları nelerdir? Örnek vererek kısaca açıklayınız.). Bu veri kaynağından öğretmen adaylarının bu öğretim modeli hakkında ne düşündüklerine dair veriler elde edilmiştir. İkinci veri toplama aracı olarak ise 3 öğretmen adayı ile yarı yapılandırılmış mülakatlar yapılmıştır. Mülakatlara katılım konusu tüm öğretmen adaylarına teklif edilmiş ancak gönüllük esasına göre 3 öğretmen adayı kabul etmiştir. Bir öğretmen adayı ise araştırma sırasında OBYM'nin aşamaları ile ilgili görüş belirtmek istemediğini ifade etmiştir. Bu öğretmen adayı ile sadece avantajlı ve sınırlı yönleri konusunda mülakat yapılmıştır. Mülakatlar ortalama 10-20 dakika sürmüştür. Analiz sonuçları bilimsel çalışma etiği gereği katılımcılara A1, A2 gibi kodlamalar ve yarı yapılandırılmış mülakatlara katılan öğretmen adaylarına ise Yıldız, Doğa ve Deniz takma isimleri verilerek sunulmuştur.

\section{Analiz}

Durum çalışmasının en önemli özelliği okuyucuya derinlemesine bir bakış açısı sunmasıdır. Bunun için de çalışmada içerik analizi ile veriler analiz edilmiştir. İçerik analizi araştırmacıların insan davranışlarını /düşüncelerini dolaylı olarak inceleme fırsatı tanıyan bir tekniktir (Fraenkel, \& Wallen, 2006). Bu nedenle veriler bir bütün oluşturacak şekilde elektronik ortama aktarılmıştır. Daha sonra veriler okunmuş ve verilen cevabın içeriğine yönelik yanlarına küçük notlar (modelin aşamaları, öğretim tekniği, avantajları, sınırlılık vb.) alınmıştır. Bu okumalar birden çok gerçekleştirilerek uygun kodlamalar (ön bilgilerin ortaya çıkarılması, kavram yanılgısı, vb.) yapılmıştır. Bu kodlamalar kategoriler (keşfetme ve sınıflandırma, yapılandırma ve müzakere etme, OBYM'nin avantajlı yönleri, vb. kategoriler; ön bilgilerin ortaya çıkarılması, kavram yanılgılarının tespit edilmesi, tartışma, grup çalışması, bilim insanı gibi çalışma, vb. gibi kodlar oluşturulmuştur.) altında toplanıp yüzdeleri belirlenerek detaylı bir içerik analizi gerçekleştirilmiştir. Ayrıca alan uzmanı başka bir araştırmacı tarafından verilerin \%10'u analiz edilmiş, araştırmacılar arası uyum incelenmiş, 0.89 oranında uyum belirlenmiştir. Kodlamalar arasında görüş birliği sağlanarak güvenirlik çalışması yapılmıştır. 


\section{Bulgular}

Bulgular çalışmanın bütünlüğünü korumak için kodlar ve yüzdeleri tablo içerisinde göstermek yerine metin içerisinde örnek ifadelerle birlikte, tüm veri kaynakları birbirinden ayrılmadan sunulmuştur. Bu doğrultuda katılımcıların sırasıyla; modelin aşamaları, avantajlar ve sınırılıklar konusundaki değerlendirmeleri aşağıda yer almaktadır.

\section{Modelin Birinci Aşaması Hakkındaki Değerlendirmeleri: Keşfetme ve Sınıflandırma}

Öğretmen adaylarının modelin birinci basamağı ile ilgili kategoride belirlenen görüşler incelendiğinde "ön bilgilerin ortaya çıkarılması", "kavram yanılgılarının tespit edilmesi" kodları ön plana çıkmaktadır. Bu aşamada ön bilgilerin ortaya çıkarıldığını belirten öğretmen adayları, grubun \%72'sini oluşturmaktadır.

"Bu basamakta öğrencinin var olan bilgi ve birikimleri ortaya çıkarılmaya çalışılır. Başlangıçta kelime ilişkilendirme testi ya da kavram karikatürü verilebilir. Örnek olarak; elektrik enerjisinin ısı ve ışık enerjisine dönüşümünü konu alırsak, başlangıçta ışık, ısı ve elektrik ile ilgili bir kelime ilişkilendirme testi ardından kavram karikatürü verilebilir.(A5)

"Öğrenci merkezli bir modeldir. Bu modelde öğrencinin bilgiye kendisinin ulaşması istenir. Bu yüzden konu ile ilgili olarak öncelikle ön bilgi sınanır. (A29)"

Kavram yanılgılarının tespit edilmesi gerektiğini ifade eden öğretmen adayı sayısı da oldukça fazladır. Grubun \%84'ü mutlaka kavram yanılgılarının tespit edilmesi gerektiğini vurgulamıştır.

"Öğrencilerin ön bilgileri, kavram yanılgıları test edilir. Yapılan etkinliklerle öğrencilerin derse olan ilgisi artabilir. Ayrıca bu modelin amacı olan öğrencinin kendi öğrenmesini gerçekleştirme sürecinin temelleri atııır. (A3)"

"Bu aşamada öğrencilerin nelerde kavram yanılgıları var onları anlamaya çalışırız. Bunu da konu örneğin "Besin zinciri ile ilgili üreticiler neden önemlidir?" ve benzeri sorular yöneltiriz. Cevaplarını vermeyiz. Öğrencilerin cevaplarını yazarız ki nerelerde kavram yanılgıları var bunu anlayalım. (A2)"

Benzer bir şekilde Yıldız ve Doğa da bu aşamada öğrencilerin ön bilgilerinin tespit edilmesi gerektiğini ifade etmiştir. Sahip oldukları kavramları nasıl algıladıkları ve varsa bu kavramlarla ilgili yanılgıların belirlenmesi gerektiğini ifade etmiştir.

Yıldız: Bu aşamasında amaç öğrencilerin hangi tip ön deneyimlerinin onların doğal dünya hakkındaki algılarını etkilediğini bulmaktı. Yani öğrencilerin doğal dünya ve sosyal ortama ne anlam yüklediklerini ve kavram yanılgılarını tespit etmek istedik.

Doğa: Keşfetme ve sınıflandırma aşamasında öğrencilerin ön bilgileri öğrenilir. Öğrencilerdeki kavram yanılgıları tespit edilir....

Yıldız bu aşamada ne tarz etkinlikler kullandıklarını da açıklamıştır. Kelime ilişkilendirme testi kullandıklarını ve soru cevap yöntemiyle bazı resim ve karikatürleri sınıflandırarak öğrencilerin ön bilgilerini ortaya çıkarmaya çalışıklarını belirtmiştir.

Yıldız: ... Bu bölümde seçtiğimiz kavramla ilgili Ki [kelime ilişkilendirme] testini yaptık. Ilgili kelime ve resimlerle çocuğun sınıflandırma yapmasını istedik. Örneğin; enerji, iş, potansiyel enerji, kinetik enerji kavramlarını ele alırsak ilk başta KiT ile çocukların algılarını ve bilgilerini test edip bu kavramlar ile resimler vererek tablolara yerleştirmelerini istedik.

Yıldız öğrencilerin grup olarak çalışmalarını istedikleri bu etkinlikle, birbirlerine saygı duymayı öğrenmelerini amaçladıklarını belirtmiştir. Bu etkinlikte öğrencilerin gözlem ve çıkarım yapmalarını beklediklerini vurgulamıştır.

Yıldız: Bu çalışma sırasında çocukların grup çalışması içinde olmasıyla çocukların birbirlerine fikirlerine olan saygıları tespit edilip, gözlem-çıkarım yaptırılmıştır.

Yıldız'ın genel olarak bu aşamada yapılması gerekenlerden haberdar olduğu tespit edilmiştir. Doğa'nın da bu aşama ilgili olarak bilimin doğasına yönelik bazı açıklamaları olmuştur. Örneğin, öğrencilerin gözlem ve çıkarım yapmalarının sağlandığını belirtmiştir. Ayrıca öğrencilerin kendilerinin de bilimsel bilgiler üretebileceklerini hissetmelerinin sağlanacağını belirtmiştir.

Doğa: ... Gözlem ve çıkarım yapmaları sağlanır. Öğrencilerin kendilerinin de bir bilimsel bilgiyi oluşturabileceği hissettirilir. 


\section{Modelin İkinci Aşaması Hakkındaki Görüşler: Yapılandırma ve Müzakere Etme}

Öğretmen adayları bu aşamada "müzakere", "tartışma", "grup çalışması" "deney ve gözlem yapma" ve "bilim insanı gibi çalışma" etkinliklerinin yapıldığını belirtmiştir. Bu ifadeleri kullanan öğretmen adayı sayısı grubun \%44'ünü oluşturmaktadır.

Öğrencilerin konu hakkında kendilerinin ve arkadaşlarının düşünceleri ortaya çıkar Bunu da beyin fırtınası, tartışma konusu ile sağlandığı basamaktır. Örneğin; elektrik enerjisi tasarrufuna ihtiyaç var mıdır? Yok mudur? gibi ikilem yaratacak sorular yönetilmelidir. (A40)

"Bu bölümde bilimin doğasıyla ilişkilendirme işlemleri ön planda olur. Öğrenci grupları kendi aralarında ve sınıf içinde görüşmeler yaparak farklı görüşler üzerinde konuşulur. (A25)

Öğretmen adayları bu bölümü, "öğrenci-öğrenci” (\%36) etkileşimin aktif olduğu aşama olarak da ifade etmişlerdir. Ayrıca bu bölümde "bilimde hayal gücü ve yaratıcılık” özelliğinin vurgulandığını belirtmişlerdir (\%20).

Burada öğretmen yalnız yönlendirendir. Öğrenci- öğrenci ilişkisi vardır. Birlikte grup olarak bir şeyleri çözüme ulaştırmaya çalışır. (A22)

Burada bilimsel bilgiyi geliştirebilmek için gerekli olan hayal gücünü ve yaratıcılığa işaret etmekte (A33)

Doğa: Yapılandırma ve müzakere etme aşamasında bilimsel bilgiyi geliştirmeyi, geliştirirken yaratııı ve hayal gücünü kullanması sağlanır.

Yıldızın bu aşama ile ilgili bilimin doğası özelliklerini daha fazla vurgulayan açıklamalarda bulunmuştur. Buna göre Yıldız, yapılandırma ve müzakere etme aşamasında bilimin doğasının hayal gücü, yaratıcılık ve bilimsel bilginin deneye dayalı doğası hakkında görüşlerini geliştirmeye odaklandıkları yönünde görüş belirtmiştir.

Yıldız: Bu aşamada bilimsel bilgiyi geliştirmek için gerekli olan hayal gücüne ve yaratıclığa önem vererek bilimsel bilginin deneye dayalı olduğu vurgulanmıştır. Seçilen kavramlar doğrultusunda çocuklardan bir tasarım yapmaları istenmiştir. Örneğin; Bir araba, cetvel ve silgi vererek arabanın hareket edebilmesi için bir yol oluşturmaları ve enerji dönüşümlerini göz önüne alarak enerji - iş ilişkisini gösteren bir tasarım yapmaları ve test etmeleri istenir.

Doğa bu aşama ile ilgili öğrencilerin deney yapma ile ilgili becerilerinin de geliştirildiğini ifade etmiştir. Ayrıca öğrencilerin kendilerini bilim insanı gibi hissetmelerinin sağlandığını belirtmiştir. Bu aşama ile ilgili olarak Doğa'nın müzakere etmeyi sağlayan herhangi bir etkinlik ya da yöntem önermediği dikkat çekmiştir.

Doğa: Deney yapma becerisi gelişir. Kendini bilim insanı olarak hisseder.

\section{Modelin Üçüncü Aşaması Hakkındaki Görüşler: Transfer Etme ve Genişletme}

Öğretmen adaylarının bu aşama ile ilgili açıklamalarını diğer aşamalara göre daha ayrıntılı yaptıkları belirlenmiştir. Bilimin sosyal ve kültürel yönünün ön plana çıktığı bu aşamayı; öğretmen adayları , "FTTÇ(\%36), günlük yaşamla ilişkilendirme (\%36), sosyo-kültürel konuların kullanıldığı (\%20)" aşama olarak ifade etmişlerdir. Var olan bilgilerin yeni bilgilere transferinin sağlanacağını belirtmişlerdir.

Bu basamakta bilgi günlük hayatla ve Fen Teknoloji Toplum ve Çevre ile ilişkilendirilir. Elektrik ile ilgili bir düzenek verilerek bu düzenek örnek alınıp kendilerinin bir düzenek tasarlamaları istenir. Genişletme evresinde bireyin hayal gücü oldukça önemlidir. Öğrenci bilgiyi kullanarak bir şeyler üretir ve bunu günlük hayatla ilişkilendirir. (A5)”

Transfer etme aşamasında günlük hayatla ilişkilendirme, sosyo-kültürel yapıya uydurma ve FTTÇ'ye yönelik etkinlikler kullanılabilir. (A19)

Bu aşamada problem çözme becerisinin geliştiği, disiplinler arası ilişkilendirme yapıldığını ifade eden öğretmen adayları da olmuştur (\%12).

Toplumsal ve çevresel sorunlara çözüm aranır. Problem çözme yeteneği geliş̧tirilir. Disiplinler arası iletişim sağlanır. (A17)

Burada diğer alanlarla etkileşim halinde olur. Disiplinler arası bir geçiş sağlanır. Bilgiyi toplumda teknolojiyle çevrede nasıl kullanacağına yönelik çalışmalara yapııır. Günlük yaşamla ilişkilendirilir. (A22)

Yıldız, öğrencilerin toplumsal ve çevre problemlerine yönlendirildiğini ve bu problemlere çözüm bulunmasına yönelik etkinlikler planladıklarını açıklamıştır. Bu planlama da tartışma ortamı oluşturmuşlar ve öğrendikleri bilgilerin günlük hayatla ilişkilendirmelerinin yapılmasını önermişlerdir. 
Yıldız: Öğrencilerin toplumsal ve çevre problemlerine yöresel ve genel problemlere çözüm bulması amaçlanır ve seçtiğimiz kavramlar doğrultusunda dünyada haberler verebiliriz ve bu haberleri kapsayan ve çevresel bir problemi sınıfta paylaşarak ne gibi önlemler, çalışmalar yapabileceği çocukla tartışılır. Günlük hayatlarılyla öğrendikleri kavramları ilişkilendirmeleri istenir.

Doğa bu aşamayla ilgili olarak; öğrencilerin, bilimin çevre ve toplumla olan ilişkisini kavrayacağını ifade etmiştir. Bir anlamda FTTÇ kazanımlarını açık olarak belirtmese de bu anlamda bir açıklama yaptığı belirlenmiştir. Çünkü açıklamasının devamında planlanan etkinliklerin öğrencilerin hayatlarını kolaylaştırdığını ifade etmiştir. Ayrıca sorunların ortadan bu bilgiler sayesinde kalkabileceğini fark etmelerini sağlayacağını belirtmiştir.

Doğa: Bilim ve çevre arasındaki etkileşimleri fark eder. Toplumun çevreyi nasıl etkilediğini fark eder. Derste yaptığı deneylerin insan hayatını kolaylaştırdığını, sorunların giderdiğini fark eder.

\section{Modelin Dördüncü Aşaması Hakkındaki Görüşler: Yansıtma ve Değerlendirme}

Bu aşamaya yönelik öğretmen adaylarının ifadelerinde genel olarak benzerlik tespit edilmiştir. Grubun \%68'i alternatif ölçme ve değerlendirme yöntemlerinin kullanılması gerektiğini belirtmişlerdir. Bu bağlamda, süreç değerlendirmesinin yapılması gerektiğini ifade eden öğretmen adayları da olmuştur.

Burada öğrenciyi anlatılan konuyu öğrenip öğrenmediğini keşfedilir. Yalnız verilen testler ya da etkinliklerle değil, süreç değerlendirme yapılır. Bilgiyi öğrenme yolunda öğrenirken neler yaşamış nasıl öğrenmiş tarzda yaklaşımlarla değerlendirme yapılır. (A22)

Öğretmen adayları değerlendirmeler sırasında bireysel farklııkların da göz ardı edilmemesi gerektiğine dikkat çekmişlerdir.

Ölçme değerlendirme klasik yöntemlerden çok bireysel farklııkları göz ardı etmeyen alternatif yöntemler kullanılır. Bu yöntemde 'öğrenci ve fikirleri' öğrencinin tartışması, sonuca ulaşması, pekiştirmesi çok önemlidir. (A29)

Öğretmen adayları alternatif ölçme değerlendirme olarak hangi tekniklerin kullanabilecekleri yönünde değerlendirmelerde de bulunmuşlardır. Kelime ilişkilendirme, kavram haritası, tanılayıcı dallanmış ağaç, yapılandırılmış grid, günlük yazma, poster, kavram çarkı ve öz değerlendirme örnek olarak verilen alternatif ölçme değerlendirme teknikleri olmuşlardır.

Bu kısımda değerlendirme yapılır. Yapılan değerlendirme sonucu eksik kalan anlaşılmayan bir konu varsa geriş dönüş yapılarak giderilmeye çalışır. Öğrenciye kelime ilişkilendirme testi, kavram çarkları gibi alternatif ölçme araçları kullanılır. (A25)

Yıldız: Geleneksel ölçme- değerlendirme yöntemleri bilgiyi ölçmekte yetersiz olduğundan alternatif ölçmedeğerlendirme yöntemleri seçilerek çocuklar değerlendirilmesi gerekir. Bu planı hazırlarken çocuklara günlük yaptırmayı, konuyla ilgili poster hazırlayıp sunmalarını uygun gördüm.

Bazı öğretmen adayları, keşfetme ve sınıflandırma evresinde kullanılan kavram yanılgısı belirleme tekniklerinin değerlendirme aşamasında da kullanılabileceğini belirtmişlerdir.

Burada değerlendirme kısmında geleneksel yöntemlerden sıyrılıp alternatif ölçme ve değerlendirme yöntemlerinin kullanılması gerekmektedir. Çünkü alternatif yöntemler daha derindeki bilgiye de ölçer ve yapılan bu etkinlikleri kolayca ortaya çıkartır. Burada kavram yanılgılarııı ne kadar giderildiğini görmek istiyorsak keşfetme ve sınıflandırmada yaptığımız (yapabileceğimiz) testi uygulayabiliriz. (A33)

Doğa: Öğrenciye geleneksel değerlendirme yanında alternatif ölçme araçları kullanıldığında öğrencinin ders başında sahip olduğu bilgi ve kavram yanılgılarının giderilip giderilmediği öğrenilmeye çalışıır.

\section{OBYM'nin Avantajı Yönleri Hakkındaki Görüşler}

Öğretmen adayları OBYM'nin öğretimde avantajlı olduğu bazı noktalara da işaret etmişlerdir. Bilimin doğasına vurgu yapması yöntemin en sık belirtilen özelliği olmuştur (\%60).

... Ayrıca bu yöntemde bilimin doğası kazanımları öğretildiğinden öğrenciler bilimin nasıl geliştiğini bilimsel bilginin nasıl ortaya çıktığını, bilim insanlarının çalışma metotlarını öğrenirler. (A3)

5E modeli yönteminden farklı olarak bilimin doğası kazanımlarına yer verilir. (A33) 
Öğrencinin aktif, sürecin öğrenci merkezli olması vurgulanmış, öğretmenin ise rehber olarak sürece dâhil olduğu belirtilmiştir (\%36).

Öğrenci merkezli bir yöntemdir. Öğretmen rehber rolündedir. (A29)

Ögrrencinin aktif olması gerekir. Öğretmen rehber olmalı (A38)

Kalıcı öğrenmelere imkân tanıdığına, öğrencilerin; yaparak, yaşayarak ve sorgulayarak öğrendiğine; fen okuryazarı bireyler olarak yetişmelerine, tasarım yapmalarına fırsat tanıdığına yönelik düşüncelerini ifade etmişlerdir (\%32).

Genel itibariyle konuyu derinlemesine ve yaşam boyu geçerli hale getirip, fen okuryazarı olmasını sağlamaktadır. (A22)

Etkili bir ders işleme yöntemidir. Öğrenci merkezli bir yaklaşım içerir. (A7)

Öğrencilerden tasarım yapmaları istenerek onların hayal gücünü geliştirmelerine olanak sağlamak yeterlidir.(A8)

Bilimi sevdirmede etkili olacağını, 5E öğrenme modelinden de eğlenceli olduğunu ifade eden bir öğretmen adayı da olmuştur.

... Ama bence 5E modeline göre daha zevkli, eğlenceli ve öğreticidir. Çünkü sadece o kazanım ya da konu hakkında durmaktansa gerek bilimle ilişkilendirmede gerekse FTTÇ ile yapılan etkinliklerle öğrencide merak ve öğrenme ihtiyacı oluşturmaktadır. (A25)

Yıldız, OBYM'nin uygulama açısından avantajlı yönleri olduğunu belirtmiştir. Fen bilimleri dersi öğretim programında yer alan FTTÇ, tutum ve değerler gibi öğrenme alanlarının bilim tarihi ile harmanlanarak konunun öğretilmesine imkân tanıdığını belirtmiştir. Böyle planlanmış bir dersin daha anlamlı öğrenmelere fırsat tanıdığını ifade etmiştir.

Yıldız: Ders planı hazırladığım süre boyunca OBYM ile FTTÇ, tutum değerlerini öğrenme modelimde uygularken içerisine bilimin tarihi gelişimini vermek, dersi sadece sığ konulardan sıyırıp o noktaya nasıl gelindiğini anlamaya daha yardımcı olabileceğimi gördüm.

Yıldız dersi planlarken, kavram yanılgılarına dikkat edilmesinin ve bu yönde materyaller geliştirilmesinin bu yanılgıları ortadan kaldırmada etkili olduğunu vurgulamıştır. Bu konuda düzenlenen etkinliklerin kendilerinin de sahip oldukları yanılgıları gidermede etkili olabileceğini ifade etmiştir.

Yıldız: Sürekli üstünde durduğumuz kavram yanılgılarına dikkat edelimin aslında sadece söyleyerek değil de materyal geliştirmekle ya da kavram karikatürleri vermekle gidermenin daha kolay olduğunu gördüm. Yapılan bütün etkinliklerde, örnek etkinliklerde, eğer gerçekten konuya uygun materyaller geliştirebilirsek fen dersinde sıkça rastladığımız ve üniversite öğrencisi olmamıza rağmen bizimde sürekli yanıldığımız konularda ki bütün sorunlardan arınabileceğimiz kanısına vardım...

OBYM'nin 5E'den farklı olarak bilimin doğasına da vurgu yaptığının altını çizmiştir. Yapılan bu uygulamanın da öğretmen olduğunda nasıl uygulayabileceği konusunda bilgi sahibi olmasına katkı sağladığını ifade etmiştir.

Yıldız:... Ayrıca OBYM'nin 5E modelinden farklı olarak bilimin doğasına vurgu yapması da önemli bir yanı bence. Aslında bu uygulamalarla bilimin doğasına öğretmen olduğumda nasıl değineceğim hakkında bilgi sahibi oldum.

Doğa'da Yıldız gibi, bu tekniği uygulama konusunda zorlandığını ifade etmiştir. Ancak avantajlı olduğu yönlerini de vurgulamıştır. Yöntemin öğrenildiğinde kolay olduğunu belirtmiştir. Bu yöntem ile öğretim yapıldığında öğrencilerin bilgiye ulaşmalarının daha kolay olduğunu ve kendi hayatlarıyla ilişkilendirme yaptıkları için daha kalıcı öğrenmeler yaşayacaklarını ifade etmiştir. Öğrencilerin bilimi ve bilimin doğasını öğrenmelerini sağladığını da belirtmiştir.

Doğa: Bu teknik çok zor görünse bile aslında öğrenilince kolay olduğu ve öğrenci bu teknikle bilgiye daha kolay ulaşır ve bilgi hayatıyla ilişkilendirerek bilginin kalıııığı sağlanır.

Doğa: ... Bilim ve bilimin doğasını öğrenmeleri sağlanır...

Deniz'in öğrencinin kendi kendine öğrenmesi, eski bilgileriyle ilişkilendirmesi açısından olumlu görüşlere sahip olduğu belirlenmiştir. Ayrıca etkili bir ders işleme yöntemi olarak değerlendirdiğini ve öğrenci merkezli olduğunu ifade etmiş̧ir.

Deniz: ortak bilgiyi yapılandırma modeli güzel bir yöntem. Keşfetme, sınıflama, geliştirme evreleri olarak çocuğa direk hazır bilgi vermiyorsun. Çocuğun kendisinden bir şeyler öğrenmesini, keşfetmesini, eskiye... geriye dönüş feedback yapmasına yardımcı oluyoruz. Bence güzel, uygulanabilir bir yöntem yani. ...

Deniz: Etkili bir ders işleme yöntemidir. Öğrenci merkezli bir yaklaşım içerir. 


\section{OBYM’nin Sınırlılıkları Hakkındaki Görüşler}

Öğretmen adayları OBYM ile ilgili bazı sınırlııklarında olduğunu dile getirmişlerdir. Ancak açıklamalarda sınırlııklara, OBYM'nin diğer özellikleri kadar çok yer verilmemiştir. Buna göre elde edilen verilerde en sık söylenen sınırlılı̆ın "zaman" olduğu tespit edilmiştir (\%20).

Zaman yetmeyebilir. (A7)

Tek sıkıntı süre, zaman açısından olabilir. (A25)

Açıklama basamağının olmadığı, bireysel farklılıkların çok olduğu sınıflarda uygulamada sıkıntılar yaşanabileceği öğretmen adayları tarafından belirtilmiştir (\%12).

Ancak bu yöntemde ögrrencinin bilgiyi keşfetmesi beklenir ve diğer yöntemlerin aksine bu yöntemde bu yüzden açıklama basamağı yoktur. ... (A29)

... Bu modelde açıklama aşaması bulunmamaktadır. (A40)

Ayrıca bireysel farklılıkları olan sınıflarda öğrencilerin ortalama seviyesine inilemeyebilir. Bazı öğrencilerin çekimser bazı öğrencilerin daha çok öne çıkmasına neden olabileceğini düşünüyorum. (A22)

Bir öğretmen adayı, öğretmenin daha fazla bilgiye sahip olması gerektiğine, kalabalık sınıflarda uygulamada sıkıntı yaşanacağına dikkat çekmiştir. Bir öğretmen adayı da her konu içeriğinde bu yöntemin uygulanamayacağına çünkü bütün konuların günlük hayatla ilişkilendirilmesinin mümkün olmadığına yönelik görüş belirtmiştir.

Öğretmenin geniş bilgisine ihtiyaç duyar. Kalabalık sınıflarda uygulamak zordur. (A2)

Her öğrencinin bilgi seviyesine uygun olmayabilir. Amaçlanmak istenen davranıs tam olarak anlatılmayabilir. Öğrenilen her bilgiyi günlük hayata uyarlamak olanaksızdır. Bu konuda OBYM tekniği her konuya uygun olmayabilir. (A19)

Yıldız bu yöntemin bazı sınırlılıkları olduğunu da ifade etmiştir. Öğrencilerin sahip oldukları kavram yanılgılarının giderilememe intimalinin de olduğunu vurgulamıştır. Ayrıca öğrencilerin süreç içerisinde yeterince aktif kılınmadığı takdirde etkinliklerin yeterli olamayacağını belirtmiştir.

Yıldız: OBYM'nin sınırıııları açısından değerlendirdiğimde ilk söyleyeceğim şey öğrencilerin kavram yanılgıları giderilmeyebilir. Öğrenciler aktif katılmasından dolayı etkinliklerin anlamı anlaşılmayabilir.

Bilimin doğası açısından da bazı sınırılıkların olabileceğini belirtmiştir. Ona göre iyi yapılandııılmamış etkinliklerde bilimin doğası yeterince vurgulanamayacaktır. Bilimin doğası etkinliklerinin örtük olarak ifade edilmesinin de öğrencilerin bilimin doğası kazanımlarına ulaşmalarına engel olacağını belirtmiş̧tir.

Yıldız. Bilimin doğası açısından da bazı sınırıııkları var bence. Mesela iyi yapılandıramadığımız etkinliklerde yeterince bilim doğasına vurgu yapılmayabiliriz. Birde öğretim sürecinde bilim doğasına kazanımlarının örtük verilmesi durumunda öğrenciler bilim doğası kazanımlarına ulaşamayabilir.

Doğa yöntemin sınırlılıklarını belirtirken bir anlamda öğretim sürecinin nasıl olması gerektiğine dair görüşler belirtmiştir. Buna göre öğrenme sürecinde bilginin öğrenciye direk verilmemesi, öğrencinin kendisinin bilgiye ulaşması gerektiğini belirtmiştir.

Doğa: Öğrenciye bilgi doğrudan verilmemelidir. Öğrenci bilgiye ulaşır. Çünkü edindiği bilgiler doğrultusunda yanlışlarını düzeltir....

Kullanılan materyaller açısından öğrenci seviyesine uygunluğuna dikkat çekmiştir. Etkinlikler açısından da sürenin doğru bir şekilde hesaplanması gerektiğine dikkat çekmiştir. Uzun süren etkinliklerin, öğrencilerin dersten uzaklaşmasına neden olacağını belirtmiştir. Ayrıca süreç içerisinde tüm öğrencilerin katılımının sağlanması gerektiğini ifade etmiştir.

Doğa: Kullanılan materyaller öğrencinin seviyesine uygun olmalıdır. ... çok uzun süre kapsamamalı öğrenciler dersten kopar. ...Tüm öğrencilerin katııımı sağlanmalıdır. Hep aynı öğrenciler aktif olmamalıdır.

Deniz, yöntemin avantajlı yönlerinden ziyade sınırlı olan yönleri konusunda görüş belirtmiştir. Sıklıkla OBYM ile 5E yöntemini kıyaslayarak açıklamalarda bulunmuştur. 5E ile aralarında farklılık olduğunu belirtmiştir. Araştırmacı bu farklılıkların ne olduğuna dair görüşlerini sorguladığında ise açıklama evresinin bu yöntemde yer almadığını ifade etmiştir. Öğretmenin bilgiyi hazır olarak öğrencilere sunmadığını belirtmiştir. OBYM'de öğretmenin sorular sorarak öğretim yaptığını; 5E de ise öğretmenin kavram yanılgılarına direk müdahale ettiğini ifade etmiştir. 
Deniz: ... 5E ile arasında fark var ama o kadar da çok fark yok diyebilirim.

Araştırmacı: Sen ne gördün mesela 5E den farklı olan?

Deniz: 5E den farklı biraz daha ayrıntıya iniyor yani ayrıntıya iniyor

Araştırmacı: Ayrıntıdan kastın nedir?

Deniz: Mesela 5E evresinde açıklama evresi vardı. Bunda mesela açıklama evresi yok. Öğretmen hazır bilgiyi direk vermiyor.

\section{Araştırmacı: Nasıl yapıyor?}

Deniz: sorular sorarak vermeye çalışıyor. Şuanda tam hatırlamıyorum da. 5E de açıklama evresi vardı. Hoca kavram yanılgılarına direkt müdahale ediyordu. Sonradan bilgiyi veriyordu. Öğrenciyi alıyordu. Ama bu ortak bilgi yapılandırma modelinde sanırım öyle bir şey yoktu gibi hatırlıyorum.

Deniz yöntemi biraz karışık olarak nitelemiştir. Bunun nedenini de yapılandırma evresinin öğrencileri zorlayacağına, özellikle öğrencilerin eski bilgileri ile ilişkilendirme konusunda zorlanacaklarına yönelik olan inancından kaynaklandığını ifade etmiştir. Ayrıca 5E yöntemini daha çok bildiği için uygulama konusunda 5E yöntemine daha fazla güvendiği belirlenmiştir. Yöntem konusunda yeterince bilgisi olduğu konusunda da çelişkili ifadelerde bulunmuştur.

Araştırmacı: Peki sence yöntemi uygulamak kolay bir şey mi? zor bir şey mi? 5 E mi daha kolay?

Deniz: Bence 5E daha kolay. Bildiğim bir yöntem. Bu yöntemle de ilgili bilgim var ama biraz karışık diye düşünüyorum

Araştırmacı: Ne açılardan karışık?

Deniz: İste bu ikinci yapılandırma evresinde biraz sanırım öğrenciler biraz zorlanabilir oralarda. Öğrendikleri bilgiler ile keşfettikleri bilgileri yapılandırmada zorlanabilir. Ama $5 E$ de mesele dediğim gibi öğretmen kavram yanılgılarına müdahale ediyor. Ama bunda ediyor mu fikrim yok. Işste müdahale ediyordu direk açıklama evresinde o kavram yanılgılarını açıklıyordu. Bu böyledir. Şu şöyledir anlatıyordu ama bu yöntemde ortak bilgi yapılandırmada eski bilgileri ile ilişkilendirme konuları öğrenciler biraz zorlanabilir diye düşünüyorum ben.

Yöntemin diğer bir sınırlılığı olarak öğretmenin rolüyle ilgili görüş belirtmiştir. Tartışma ortamının öğretmen tarafından iyi yönetilmesi gerektiğini ifade etmiştir. Ayrıca kavramları açıklarken çocukların zihinlerinde soru işareti bırakmadan açıklanması, eski konularla ilişkilendirme konusunda yardımcı olunması gerektiğini belirtmiştir. Bu noktada öğretmenin söz konusu konularda yeterince donanımlı olması gerektiğini de dikkat çekmiştir. Ayrıca uygulama süresinin fazla olabileceğini de belirtmiştir.

Deniz: Dediğim gibi hocam tartışma ortamını çok iyi yönetmek gerekiyor. Bu da öğretmenin performansına bakıyor. Öğretmenin bayağı bilgili olması gerekiyor. Kavramları hiç çocuklarda soru işareti bırakmadan açıklaması gerekiyor. irdelemesi gerekiyor. Yani ilişkilendirmesi gerekiyor eski bilgilerle de. Çocuk 6. 7. sınıfta bu yöntemi bir x ünitesinde işledin. Ortak bilgiyle anlattın ama 6. Sınıfa da geri dönüş yapman gerekiyor. Senin onu bilmen gerekiyor yani zaten biliyorsunuzdur da onları bir yoklaman gerekiyor diye düşünüyorum. ... Zaman yetmeyebilir. Uygularken uzun zaman alabilir bir de.

\section{Sonuç ve Tartışma}

Bu araştırmada OBYM ile bilimin doğasına yönelik ders planı hazırlayan öğretmen adaylarının bu model hakkındaki görüşleri incelenmiştir. Araştırma sonuçları OBYM ile öğrenme süreçlerinin tasarımında ve öğretim aşamalarında dikkat edilmesi gereken hususların belirlenmesinde öğreticilere yol gösterici olacağı düşünülmektedir. Öğretmen adaylarının OBYM yöntemi ile ilgili görüşlerinin incelenmesi sonucunda, modelin genel yapısına hâkim oldukları belirlenmiştir. Öğretmen adaylarına modelin önerdiği gibi bilimin doğası öğretimi bağlamında ders planlamaları yönünde yapılan yönlendirmenin, modelle ilgili görüşlerinde önemli bir farklılık oluşturmadığı belirlenmiştir.

Öğretmen adayları OBYM'nin her bir aşamasını değerlendirmiş ve bu doğrultuda görüşlerini belirtmişlerdir. Örneğin, OBYM'nin ilk aşaması olan keşfetme ve sınıflandırmayla ilgili görüşlerinin, modelin önerileriyle benzerlik gösterdiği belirlenmiştir. Modelin bu basamağında "ön bilgilerin ortaya çıkarılır", "kavram yanılgılarının tespit edilir". Kelime ilişkilendirme, soru cevap yöntemleri kavram yanılgılarının tespitinde kullanılabilecek tekniklerdir. Bu aşamada modelin önerisinden farklı olarak bilimin doğası özelliklerinden özellikle gözlem ve çıkarım arasındaki farkın vurgulanabileceği öğretmen adaylarınca belirtilmiştir. Bakırcı'nın (2014) araştırmasında katılımcı olan öğretmenlerin tümü ile Çelik, Pektaş ve Karamustafoğlu (2018)'nun çalışmasına katılan öğretmen adayları, bu aşamanın uzun olduğu 
yönünde bir eleştiri getirmişlerdir. Ancak araştırmaya katılan öğretmen adayları keşfetme ve sınıflandırma aşamasının uygulanmasındaki bu olumsuzluklardan bahsetmemişlerdir.

Öğretmen adayları modelin tartışma ortamı oluşturulması, grup çalışması gibi etkinliklerin ön planda olduğunu belirtmişlerdir. Öğrenci-öğrenci etkileşiminin yapılandırma ve müzakere etme aşamasında yoğun olduğu yönünde bir değerlendirme yapmışlardır. Akgün, Duruk ve Gülmez-Güngörmez'in (2016) araştırmasına katılan öğrenciler de bu modelin akranlarıyla olan iletişimi arttırdığı yönünde görüş belirttiklerini ifade etmişlerdir. Bu aşama sırasında deney ve gözlem yapma, bilim insanı gibi çalışma etkinliklerinin de yapılabildiği öğretmen adaylarınca belirtilmiştir. Benzer sonuçlar Bakırcı, Çepni ve Ayvacı (2015) çalışmasında da ortaya çıkmıştır. Fen ve Teknoloji öğretmenlerinin model hakkında görüşlerinin değerlendirildiği bu çalışmada öğretmenlerin, öğrencilerin bilgiyi sadece bilimsel yöntemleri kullanarak kazanmadıklarını bunun yanında görüşlerini paylaşarak ya da tartışarak daha sosyal boyutlarla da ifade edebileceklerini belirtmişlerdir. Ayrıca bu bölüm öğretmen adaylarınca bilimin doğası özelliklerinin de sunulduğunun farkında oldukları bir aşama olarak değerlendirilmiştir. Özellikle "bilimde hayal gücü ve yaratıcılık" ve "bilimsel bilginin deney ve gözlemlerden elde edilmiş verilere dayalı doğası" özelliklerinin vurgulanabileceğini belirtmişlerdir.

Öğretmen adaylarının transfer etme ve genişletme aşaması ile ilgili açıklamalarını diğer aşamalara göre daha ayrıntılı olduğu belirlenmiştir. Öğretmen adayları bu aşamanın özellikle bilimin sosyal ve kültürel yönünün ön plana çıkartıldığı, günlük hayatla ilişkilendirilmenin gerçekleştirildiği, öğrencileri problem çözmeye yönlendirildiği ve bu becerilerini, geliştirmeye yönelik bir aşama olarak değerlendirmişleridir. Özellikle fen-teknoloji-toplum-çevre ilişkisi ve disiplinler arası ilişkilendirmelere dikkat çekmişlerdir. Yenilenen 2017 fen bilimleri öğretim programına eklenen fen ve mühendislik uygulamaları yönelik içerikler göz önünde bulundurulduğunda, modelin bu aşamasında eğer içerik doğru uygulanırsa programın yeni hedeflerine paralel bir eğitim de verilebileceği ortaya çıkmaktadır. Öğretmen adayları bu aşamada sosyo-bilimsel konuların, dünyadan haberler ya da çevresel haberler gibi etkinliklerle yoluyla yer verilebileceğini de ifade etmişlerdir. Bakırcı'nın (2014) araştırmasına katılan öğretmenler her konuda sosyo-bilimsel konu bulmanın zorluğuna da işaret etmişlerdir. Benzer bir şekilde bu araştırmaya katılan öğretmen adayları da her konu içeriğinde bu yöntemin uygulanamayacağı, çünkü bütün konuların günlük hayatla ilişkilendirilmesinin mümkün olmadığı yönünde değerlendirmeler yapmıştır.

Yansıtma ve değerlendirme aşamasına yönelik öğretmen adaylarının ifadelerinde genel olarak benzerlik tespit edilmiştir. Grubun büyük bir çoğunluğu alternatif ölçme ve değerlendirme yöntemlerinin kullanılması gerektiğini belirtmişlerdir. Böylece daha önceden sahip olunan kavram yanılgılarının giderilip giderilmediği konusunda bilgi sahibi olunabileceğine dikkat çekmişlerdir. Bu bağlamda, süreç değerlendirmesinin yapılması gerektiğini ifade eden öğretmen adayları da olmuştur. Bireysel farklılıkları göz önünde bulunduran alternatif yöntemlerin tercih edilmesine de dikkat çekilmiştir. Keşfetme ve sınıflandırma evresinde kullanılan kavram yanılgısı belirleme yöntemlerinin, değerlendirme aşamasında da kullanılabileceğini ifade eden öğretmen adaylarının da olduğu belirlenmiştir. Bu yaklaşım, bir anlamda modelin aşamaları arasındaki ilişkinin öğretmen adaylarınca kavrandığının da bir göstergesi olarak değerlendirilmiştir.

Bakırcı (2014), OBYM hakkında öğretmenlerin görüşlerini belirlemiştir. Buna göre Fen ve Teknoloji öğretmenleri üç konuda ortak görüş öne sürmüşlerdir. Bunlar OBYM'nin avantajlarını yönünden içeriklerdir ve şöyle sıralanmıştır; model bilimin doğasına vurgu yapmaktadır, değerlendirme açısından tamamlayıcı ölçme değerlendirme ön plana çıkmıştır, bilginin sosyal boyutunun bilgi yapılandırılması sırasında tartışıımasıdır. Bu araştırmada benzer sonuçlar elde edilmiş, ayrıca öğretmen adaylarının OBYM'nin öğretimde kavramsal değişim, bilimi sevdirme konularında işaret ettikleri gözlenmiştir. Bilimin doğasına vurgu yapılması modelin en sık belirtilen özelliği olmuştur. Bilimin doğasının, modelin öğrenme ortamında öğretimine vurgu yapılan önemli özelliklerden biri olmasının (Biernacka 2006; Çepni ve diğer., 2012; Ebenezer ve diğer., 2010; Ebenezer ve Fraser, 2001; Wood, 2012) aynı zamanda da araştırma sürecinin özellikle bilimin doğası öğretimine odaklanılmasının bu konuda etkisi olduğu düşünülmektedir. Modelin sıkça vurguladığı kavramsal değişim, kavram yanılgıların giderilmesi özelliği öğretmen adaylarınca belirtilmiştir. Modelin öğrencilerin kavramsal anlamalarına ve akademik başarılarının gelişimine katkı sağladığı araştırmacılarca da belirlenmiştir (Biernacka, 2006; Kıryak ve Çalık, 2017; Wood, 2012). Öğrencinin aktif, sürecin öğrenci merkezli olması, öğretmenin ise rehber olarak sürece dâhil olduğu vurgulanmıştır. Öğretmen adaylarınca da belirtilen OBYM'nin bu özelliği, hem 2013 öğretim programı (Bakırcı ve Çepni, 2014) ile hem de yeni öğretim programının amaçları ile benzerlik göstermektedir. Öğretmen adayları kalıcı öğrenmelere imkân tanıdığına, öğrencilerin; yaparak, yaşayarak ve sorgulayarak öğrendiğine; fen okuryazarı bireyler olarak yetişmelerine yönelik düşüncelerini ifade etmişlerdir. Öğretmen adaylarının 2013 fen bilimleri öğretim programı içeriğine paralel olan bu düşünceleri, programın içeriğine hâkim olmalarının da bir sonucudur. Bilimi sevdirmede etkili olacağını, 5E öğrenme modelinden de eğlenceli olduğunu 
ifade edilmiştir. Akgün, Duruk ve Gülmez-Güngörmez (2016) ile Taşkın ve Yıldız'ın (2011) çalışmalarına katılan katılımcılarda OBYM ile işlenen derslerin eğlenceli olduğunu ifade etmeleri bu çalışmaya paralellik göstermektedir.

Öğretmen adayları OBYM ile ilgili bazı sınırlılıkların da olduğunu dile getirmişlerdir. Ancak açıklamalarda sınırlııklara, OBYM'nin diğer özellikleri kadar çok yer verilmemiştir. Çünkü öğretmen adayları bu modeli ilk olarak uygulama konusunda zorlandıklarını ama modeli öğrendiklerinde kolay olduklarını belirtmişlerdir. Buna göre elde edilen verilerde en sık söylenen sınırılığın "zaman" olduğu tespit edilmiştir. Açıklama basamağının olmadığı, bazı öğretmen adayları tarafından belirtilmiştir. Benzer sınırlılık Bakırcı'nın (2014) araştırmasına katılan öğretmenler tarafından da dile getirilmiştir. Bakırcı bu durumu öğretmenlerin $5 \mathrm{E}$ öğretim modeline alışmış olmaları ile açıklanabileceğini belirtmiştir. Bu durum bu araştırmaya katılan katılımcılar için de söylenebilir. Bireysel farklılıkların çok olduğu ve kalabalık sınıflarda uygulamada sıkıntılar yaşanabileceği öğretmen adayları tarafından belirtilmiştir. Öğretmenin daima daha fazla bilgiye sahip olması gerektiğine dikkat çekilmiştir. Çelik, Pektaş ve Karamustafaoğlu (2018)'nın araştırmasında da öğretmen adayları alan bilgisi yetersizliğinin bu modelin uygulanmasında bir dezavantaj olarak gördüklerini belirtmişlerdir.

Araştırma sonuçları öğretmen adaylarının OBYM ve uygulanışı hakkında farkındalıklarının olduğu ve modelin doğasına paralele görüş belirttikleri görülmektedir. Benzer şekilde fen bilgisi öğretmenlerinin de öğretim programının önemli bir öğesi olan OBYM ile öğretimin önemi hakkında farkındalığı sağlanmalıdır. Bu doğrultuda farkı bir öğretim yönteminin/modelinin öğretmen adaylarınca değerlendirileceği bir araştırmada katılımcılara benzer bir eğitim içeriği tasarlanarak sunulması önerilmektedir. Çünkü böylelikle model hakkında daha fazla fikir sahibi olacaklardır. Bu araştırma da öğretmen adayları bilimin doğası bağlamında ders planlayarak modeli değerlendirmelerine karşın bilimin doğası ve OBYM ilişkisine özel bir ilişkilendirme yapmadıkları sadece OBYM'nin bilimin doğası öğretimini desteklediğine yönelik görüş belirtmişlerdir. OBYM ile bilimin doğasına yönelik ders planlayacak eğitimciler ve araştırmacılar için öğretmen adaylarınca belirtilen öneriler şu şekildedir; keşfetme sınıflandırma aşamasında: gözlem ve çıkarım arasındaki fark vurgulanabilir; yapılandırma ve müzakere etme aşamasında; hayal gücü ve yaratıcılık, bilimsel bilgiler deney ve gözlemlerden elde edilmiş verilere dayalıdır, bilim insanları nassıl çalışır? konuları tartışılabilir, deney ve gözlem yaptırılabilir; transfer etme ve genişletme aşamasında: bilimin sosyal ve kültürel yapısı hakkında ilişkilendirme yapılabilir. Ayrıca araştırmacılara; sosyo-bilimsel konular, FTTÇ gibi modelin ön plana çıkardığı diğer bağlamlarda ya da fen dışındaki başka bir alanda yaşanacak süreçlerin de benzer sonuçlar ortaya koyup koymayacağının araştırılması önerilmektedir.

\section{Kaynakça}

Abd-El-Khalick, F., \& Lederman, N. G. (2000). The influence of history of science courses on students' views of nature of science. Journal of research in science teaching, 37(10), 1057-1095.

Akgün, A., Duruk, Ü. ve Gülmez Güngörmez, H. (2016). Altıncı sınıf öğrencilerinin ortak bilgi yapılandırma modeline ilişkin görüşleri. Amasya Üniversitesi Eğitim Fakültesi Dergisi, 5(1), 184-202. doi:10.17539/aej.52527

Aslan, O., \& Tasar, M. F. (2013). How do science teachers view and teach the nature of science? A classroom investigation. Education and Science, 38(167), 65-80.

Ay, Ş. (2013). Öğretmen adaylarının proje tabanlı öğrenme ve geleneksel öğretime ilişkin görüşleri. Hacettepe Üniversitesi Eğitim Fakültesi Dergisi [Hacettepe University Journal of Education], 28(1), 53-67.

Bakırcı, H. (2014). Ortak bilgi yapılandırma modeline dayalı öğretim materyali tasarlama, uygulama ve modelin etkililiğini değerlendirme çalışması: Işık ve ses ünitesi örneği. Yayımlanmamış Doktora Tezi, Karadeniz Teknik Üniversitesi, Eğitim Bilimleri Enstitüsü, Trabzon.

Bakırcı, H., Artun, H., Şahin, S. ve Sağdıç, M. (2018). Ortak bilgi yapılandırma modeline dayalı fen öğretimi aracılığıyla yedinci sınıf öğrencilerinin sosyobilimsel konular hakkındaki görüşlerinin incelenmesi. Eğitimde Nitel Araştırmalar Dergisi- Journal of Qualitative Research in Education, 6(2), 207-237. DOI:10.14689/issn.2148 - 2624.1.6c2s10m

Bakırcı, H., Çalık, M., \& Çepni, S. (2017). The effect of the common knowledge construction model-oriented education on sixth grade pupils' views on the nature of science. Journal of Baltic Science Education, 16(1), 43-55.

Bakırcı, H. ve Çepni, S. (2012). Fen ve teknoloji öğretimi için yeni bir model: Ortak bilgi yapılandırma modeli. X. Ulusal Fen Bilimleri ve Matematik Eğitimi Kongresi'nde sunulmuş bildiri, Niğde.

Bakırcı, H. ve Çepni, S. (2014). Fen bilimleri dersi öğretim programı temelinde ortak bilgi yapılandırma modelinin irdelenmesi. Fen Bilimleri Öğretimi Dergisi, 2(2), 83-94.

Bakırcı, H , Çepni, S. ve Ayvacı, H . (2015). Ortak bilgi yapılandırma modeli hakkında fen bilimleri öğretmenlerinin görüşleri. Yüzüncü Yıl Üniversitesi Eğitim Fakültesi Dergisi, 12 (1), 97-127. 
Biernacka, B. (2006). Developing scientific literacy of grade five students: A teacher researcher collaborative effort. Unpublished Ph.D. dissertation, University of Manitoba.

Bozdoğan, A.E., ve Altunçekiç, A. (2007). Fen bilgisi öğretmen adaylarının 5E öğretim modelinin kullanılabilirliği hakkındaki görüşleri. Gazi Üniversitesi Kastamonu Eğitim Fakültesi Dergisi, 15(2), 579-590.

Caymaz, B. ve Aydın, A. (2017). Ortak Bilgi Yapılandırma Modelinin Yedinci Sınıf Öğrencilerinin Elektrik Enerjisi Ünitesine Illişkin Kavramsal Anlamalarına Etkisi. Kastamonu Eğitim Dergisi,27(5), 1-10. DOI: 10.24106/kefdergi.3196

Çelik, H., Pektaş, H.M. \& Karamustafaoğlu, O. (2018). Science teaching laboratory applications: common knowledge construction, learning cycle models and STEM approach, International Journal on New Trends in Education and Their Implications, 9(3), 1129.

Çepni, S., Özmen, H. ve Bakırcı, H.(2012). Ortak bilgi yapılandırma modeline uygun öğretim materyallerinin geliştirilmesi: "Işığın madde ile etkileşimi ve yansıma örneği. X. Ulusal Fen Bilimleri ve Matematik Eğitimi Kongresinde sunulmuş bildiri, Niğde.

Demircioğlu, H. ve Vural, S. (2016). Ortak bilgi yapılandırma modelinin sekizinci sınıf düzeyindeki üstün yetenekli öğrencilerin kimya dersine yönelik tutumları üzerine etkisi [Special Issue-1]. Hasan Ali Yücel Eğitim Fakültesi Dergisi, 13(1), 49-60.

Doğan, N., Çakıroğlu J., Bilican, K., \& Çavuş, S. (2013). What NOS teaching practices tell us: a case of two science teachers. Journal of Baltic Science Education, 12(4), 424-439.

Ebenezer, J.V. \& Connor, S. (1998). Learning to Teach Science: A Model for the 21 Century. Upper Saddle River, New Jersey: Prentice-Hall.

Ebenezer, J., Chacko, S., Kaya, O.N., Kaya, S. K. \& Ebenezer, D.L. (2010). The effects of common knowledge construction model sequence of lessons on science achievement and relational conceptual change. Journal of Research in Science Teaching, 47(1). 25-46.

Ebenezer, J.V. \& Fraser, D. (2001). First year chemical engineering students" conceptions of energy in solution process: Phenomenographic categories for common knowledge construction. Science Education, 85, 509-535.

Faikhamta, C. (2013). The development of in-service science teachers' understanding of and orientations to teaching the nature of science within a PCK-based NOS course. Research in Science Education, 43(2), 847-869.

Fraenkel, J.R., \& Wallen, N.E. (2006). How to design and evaluate research in education. 6th Edition, Boston: McGraw Hill.

Hanuscin, D. L., Lee, M. H., \& Akerson, V. L. (2010). Elementary teachers' pedagogical content knowledge for teaching the nature of science. Science Education, 95(1),145-167.

Karaman, P. (2014). Öğretmen adaylarının ölçme-değerlendirme okuryazarlıklarının belirlenmesi ve mikro-öğretim yoluyla geliştirilmesi. Yayımlanmamış doktora tezi, Çanakkale Onsekiz Mart Üniversitesi Eğitim Bilimleri Enstitüsü, Çanakkale.

Kıryak, Z. (2013). Ortak bilgi yapılandırma modelinin 7. sını öğrencilerinin su kirliliği konusundaki kavramsal anlamalarına etkisi. Yayımlanmamış yüksek lisans tezi, Eğitim Bilimler Enstitüsü, Karadeniz Teknik Üniversitesi, Trabzon.

Kıryak, Z. \& Çalık, M. (2017). Improving grade 7 students' conceptual understanding of water pollution via common knowledge construction model. International Journal of Science and Mathematics Education, 1-22.

Lederman, N.G. (2007). Nature of sciene: Past, present, and future. In Abell, S. K., \& Lederman, N. G. (Eds.), Handbook of research on science education (pp. 831-879). Mahwah, NJ: Lawrence Erlbaum Associates.

Lederman, N. G., \& Lederman, J.S. (2012). Nature of scientific knowledge and scientific inquiry: Building instructional capacity through professional development. Barry J. Frase, Kenneth G. Tobin, \& Campbell J. McRobbie (Ed.), In second international handbook of science education (S. 335-360). New York: Springer.

Milli Eğitim Bakanlığı [MEB] (2013). Ilköğretim kurumları fen bilimleri dersi (3-8. sınıflar) öğretim programı, Ankara: Milli Eğitim Bakanlığı.

Menon, D., Sinha, S., \& Hanuscin, D. (2012, January) Professional journals as a source of information about teaching NOS: An examination of articles published in Journal of College Science Teaching, 1996-2010.Paper presented at the annual meeting of the Association for Science Teacher Education. Cleawater, FL.

Merriam, S. B. (2013). Nitel araştırma. Desen ve uygulama için bir rehber. (S. Turan. Çev.). Ankara: Nobel.

Namdar, B. ve Tuskan, İ.B. (2018). Fen bilgisi öğretmenlerinin argümantasyona yönelik görüşleri. Hacettepe Üniversitesi Eğitim Fakültesi Dergisi (H. U. Journal of Education) 33(1): 1-22. doi: 10.16986/HUJE.2017030137

Pongsanon, K. (2012). Fostering nature of science teaching in elementary pre-service teachers through developing reflection on teaching and learning (Order No. 3552635). Available from ProQuest Dissertations \& Theses Global. (1312344559). Retrieved from https://search.proquest.com/docview/1312344559?accountid=15572

Sadler, T. D., Burgin, S., McKinney, L., \& Ponjuan, L. (2010). Learning science through research apprenticeships: A critical review of the literature. Journal of Research in Science Teaching, 47(3), 235-256.

Schwartz, R. S., \& Crawford, B. A. (2004). Authentic scientific inquiry as a context for teaching nature of science: Identifying critical elements for success. In Flick, L., \& Lederman, N. (Eds.).Scientific Inquiry and Nature of Science: Implications for Teaching, Learning, and Teacher Education. Dordrecht, The Netherlands: Kluwer. 
Smylie, M. A. (1989). Teachers' views of the effectiveness of sources of learning to teach. The Elementary School Journal, 89, 543558.

Stake, R.E. (2005). Qualitative case studies. In. N. K. Denzin \& Y. S. Licoln (Eds.). The Sage Handbook of Qualitative Research, London: Sage.

Şahin, B. (2009). Metodoloji, bilimsel araştırma yöntemleri. A. Tanrı̈ğen (Editör), Bilimsel Araştırma Yöntemleri, Ankara: Anı.

Taşkın, D. ve Yıldız, C. (2011, A pril). Kesirlerde toplama ve çıkarma işlemlerinin öğretimine common knowledge construction modele uygun materyal geliştirme. 2nd International Conference on New Trends in Education and Their Implications, Antalya-Turkey.

Topuz, F, Gençer, S, Bacanak, A, ve Karamustafaoğlu, O . (2013). Bağlam temelli yaklaşım hakkında fen ve teknoloji öğretmenlerinin görüşleri ve uygulayabilme düzeyleri. Amasya Üniversitesi Eğitim Fakültesi Dergisi, 2(1), $240-261$.

Wood, L.C. (2012). Conceptual change and science achievement related to a lesson sequence on acids and bases among African American alternative high school students: a teacher's practical arguments and the voice of the "other". Unpublished Ph.D. Dissertation, Wayne State University.

Yıldırım, B., ve Türk, C. (2018). Sınıf öğretmeni adaylarının STEM eğitimine yönelik görüşleri: Uygulamalı bir çalışma. Trakya Üniversitesi Eğitim Fakültesi Dergisi, 8(2), 195-213.

Yin R. K. (2003). Case study research: design and methods. (Third edition.). Thousand Oaks: Sage. 